\title{
TRADE EFFECTS OF REGIONAL STANDARDS LIBERALIZATION A HETEROGENEOUS FIRMS APPROACH
}

\author{
Silja Baller* \\ World Bank
}

\begin{abstract}
This study investigates trade effects of the regional liberalization of technical barriers to trade (TBTs) in the form of harmonization and mutual recognition agreements (MRAs) for testing procedures. The theoretical part of the paper is framed in terms of a heterogeneous firms approach. This paper adds to the existing literature by formalizing the effects of MRAs and harmonization initiatives on bilateral trade flows and by applying this new theoretical framework in the empirical part of the paper. The latter consists of a two-stage gravity estimation and investigates sectoral effects of regional TBT liberalization on parties to the agreement as well as excluded industrialized and developing countries. It finds that MRAs have a strong positive influence on both export probabilities and trade volumes for partner countries. Regarding harmonization, results seem to suggest that the impact on parties to the agreement is negligible, however that on excluded OECD countries is large and positive. Third party developing countries do not seem to benefit from the market integration effect brought about by harmonization in other regions. Overall, effects on the probability that a new firm will export are much more pronounced than effects on the trade volumes of incumbent exporters.
\end{abstract}

World Bank Policy Research Working Paper 4124, February 2007

The Policy Research Working Paper Series disseminates the findings of work in progress to encourage the exchange of ideas about development issues. An objective of the series is to get the findings out quickly, even if the presentations are less than fully polished. The papers carry the names of the authors and should be cited accordingly. The findings, interpretations, and conclusions expressed in this paper are entirely those of the authors. They do not necessarily represent the view of the World Bank, its Executive Directors, or the countries they represent. Policy Research Working Papers are available online at http://econ.worldbank.org.

\section{Acknowledgements}

The author has benefited from the guidance of and helpful discussions with Richard Baldwin and Mona Haddad as well as valuable comments from Paul Brenton, John Cuddy, Barbara Fliess, Sudarshan Gooptu, Marion Jansen, Patrick Low, Marc Melitz, Roberta Piermartini, Benjamin Shepherd and John Wilson.

* Correspondence: sballer@,worldbank.org, East Asia and Pacific Region, Poverty Reduction and Economic Management Sector 


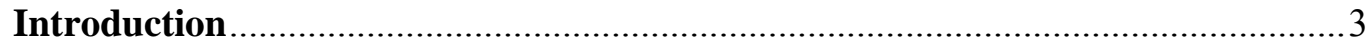

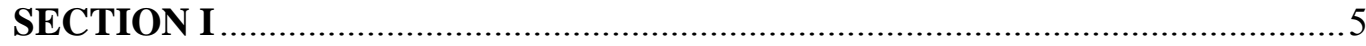

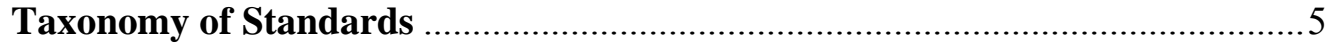

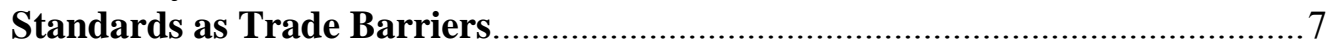

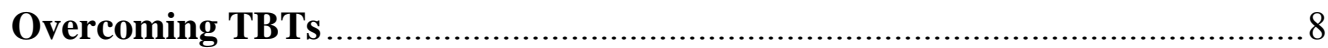

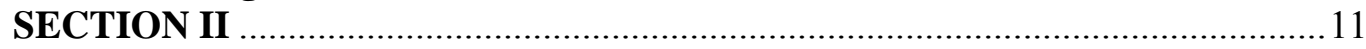

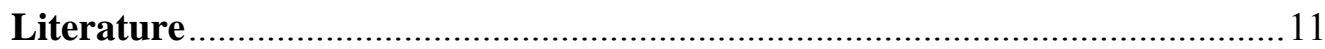

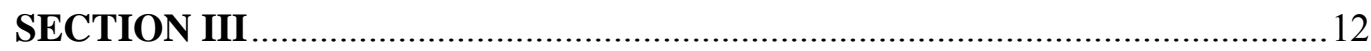

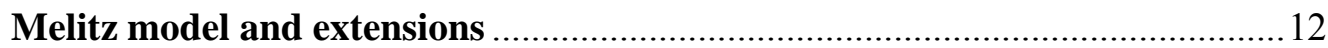

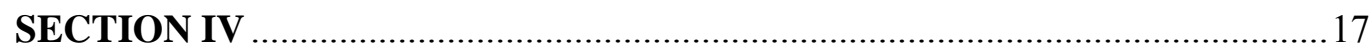

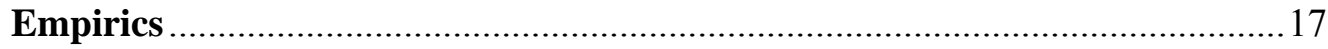

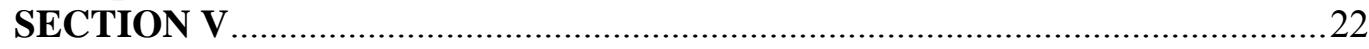

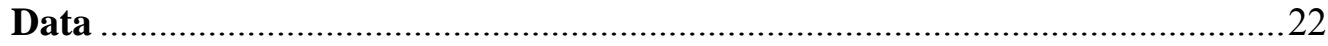

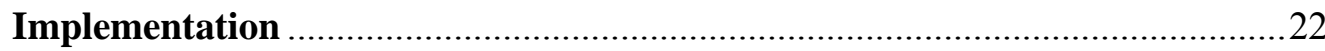

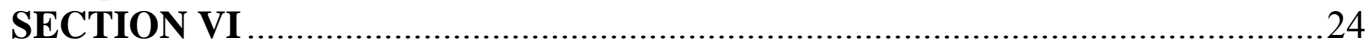

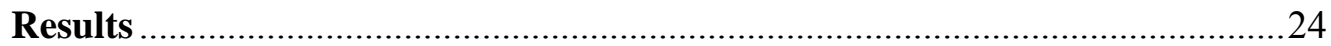

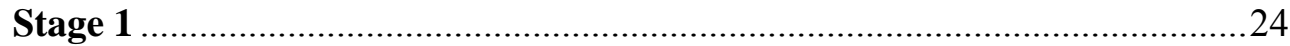

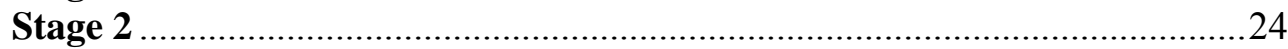

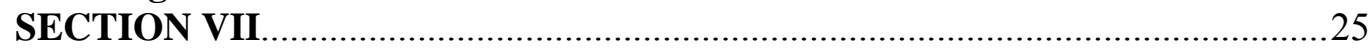

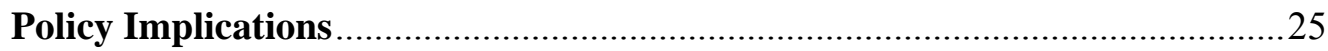

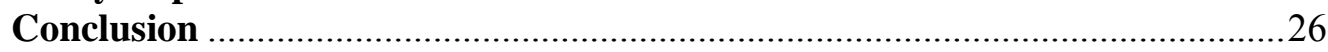

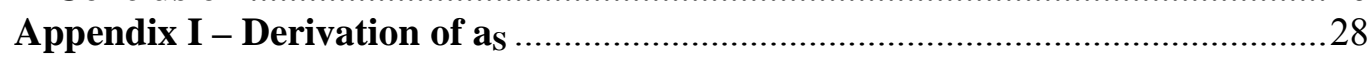

Appendix II - Derivation of the empirical specification following HMR .............31

Appendix III - Countries included in the sample ...............................................33

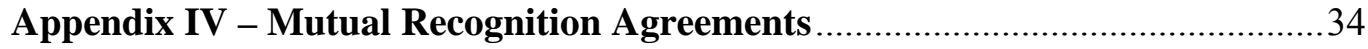

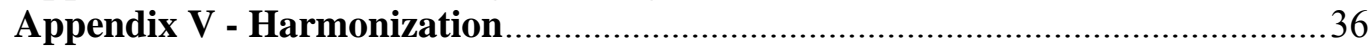

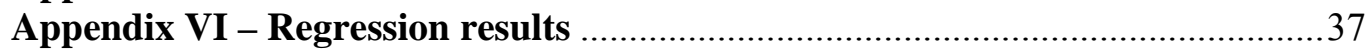

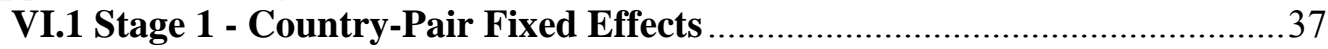

VI.2 Stage 1 - Exporter-, Importer- and Year-Fixed Effects ............................38

VI.3 Stage 2 - Exporter-, Importer, and Year-Fixed Effects OLS Corrected for

Heckman Selection Bias and Heterogeneity Bias via yhat ..............................39

$\begin{array}{ll}\text { Bibliography } & 40\end{array}$ 


\section{Introduction}

As the $20^{\text {th }}$ century drew to a close, GATT's original goal of a gradual abolishment of tariffs and quotas had been achieved to a considerable extent. Yet, as Robert Baldwin points out as early as 1970, this leaves the playing field still far from level: "The lowering of tariffs has, in effect, been like draining a swamp. The lower water level has revealed all the snags and stumps of non-tariff barriers that still have to be cleared away." With tariff barriers becoming increasingly less important, differences in national regulatory regimes are becoming ever more visible. These regulatory regimes include areas as varied as government procurement rules, inward foreign investment, competition policy, labor standards and environmental norms as well as product standards and technical regulations (Hoekman, Mattoo, English, 2002).

This paper has singled out technical regulations (termed technical barriers to trade or TBTs in the WTO context) as one particular domestic regulatory regime and will analyze the means that have been employed in recent years to overcome the negative trade-effects thereof.

Firm-level surveys conducted in both industrial and developing countries, consistently identify technical regulations (along with rules of origin and customs procedures) as the main non-tariff export constraint (World Bank TBT Survey, 2004; OECD metasurvey 2003). Richard Baldwin (2000) points out that TBTs have been the main concern of the EU as far as trade barriers are concerned ever since the abolishment of all internal tariffs in 1973. In the context of the recently launched trade talks between the EU and ASEAN, Pascal Lamy expressed the belief that harmonizing standards and rules in areas such as safety, health or consumer protection rather than abolishing tariffs and quotas, were "the real $21^{\text {st }}$ century trade issues". ${ }^{1}$ The urgency of the topic is further underlined by the significant rise in WTO dispute settlement case load that turns on standards-related issues.

This study will investigate trade effects of TBT liberalization in the form of harmonization and mutual recognition agreements for testing procedures (MRAs). The theoretical part of the paper is framed in terms of Melitz's (2003) heterogeneous firms approach. The paper develops Melitz's model so as to formalize the effects of MRAs and harmonization initiatives on bilateral trade flows and applies this new theoretical framework in the empirical part of the paper. The latter consists of a twostage gravity estimation and investigates sectoral effects of TBT liberalization on parties to the agreement as well as excluded industrialized and developing countries respectively.

In Section I, technical issues surrounding standards as well as liberalization efforts in this area will be discussed. Different types of standards will be defined and classified. The paper will subsequently focus only on government imposed technical regulations. The various categories of legal instruments that have been employed to overcome trade-distorting effects connected to them will be discussed. The analysis will then focus on harmonization initiatives and mutual recognition agreements (MRAs) of testing procedures as two such instruments.

\footnotetext{
${ }^{1}$ quoted in Chen and Mattoo (2004)
} 
Section II provides a brief overview of the existing theoretical and empirical literature on the topic, which is currently not very extensive. Most empirical papers on the subject lack sound theoretical underpinnings, a weakness that this paper attempts to overcome.

Sections III and IV discuss the theoretical model and empirical derivation upon which the analysis will be based. Within these sections, the existing theory is developed so as to formalize issues arising from TBT liberalization. In Melitz (2003), the decision of a firm to enter into an export market hinges crucially on the level of fixed cost in a given market. It is here, that technical barriers to trade as an important type of fixed export cost are introduced into the model. TBT liberalization can then take the form of MRAs - modelled in this paper as a reduction in fixed export cost - or complete harmonization - modelled here as an elimination of fixed costs for all but the home market, such that a firm is now making a joint entry decision for all markets in the harmonizing region. Despite the fact that formally modelling effects of such preferential liberalization agreements on excluded countries is beyond the scope of this paper, this aspect is included in the empirical part.

Crucially, in particular for the empirical analysis, Melitz points to two margins of adjustment for trade flows arising from the endogenous firm selection process: the volume of trade flows will be determined by the volume of exports by each individual exporting firm (the intensive margin) as well as the fraction of firms actually exporting (the extensive margin). This theoretical background gives rise to a twostage estimation structure, where the first stage consists of a probit gravity equation yielding a proxy for the extensive margin. The latter is then used to correct for heterogeneity bias in the second stage of the estimation, which is an otherwise standard gravity equation (in effect a Tobit II model with correction for firm heterogeneity).

Implementation issues are discussed in Section V. The analysis is conducted at the sectoral level, focusing on the telecoms and medical device industries. It is found that MRAs have a strong positive influence on both export probabilities and trade volumes for partner countries. Regarding harmonization, results seem to suggest that the impact on parties to the agreement is negligible, however that on excluded OECD countries is large and positive. Excluded developing countries generally do not seem to benefit from the market integration effect brought about by harmonization in other regions. Overall, effects on the probability that a new firm will export are much more pronounced than effects on the trade volumes of incumbent exporters. Results are robust across different time periods and sectors. All results are discussed in detail in Section VI. 


\section{SECTION I}

\section{Taxonomy of Standards}

Technical barriers to trade can be seen as resulting from standards that specify either product characteristics or process and production methods. Baldwin (2000) distinguishes between two aspects of these standards (both of which create a barrier): i) content of the standard and ii) testing procedures necessary to demonstrate that a product complies with a given standard.

The WTO defines a standard as follows:

(...) standards set out specific characteristics of a product - such as its size, shape, design, functions and performance, or the way it is labeled or packaged before it is put on sale. In certain cases, the way a product is produced can affect these characteristics, and it may then prove more appropriate to draft (...) standards in terms of a product's process and production methods rather than its characteristics per se. (...)

Given this definition, this section describes the three situations where standards are necessary. These are (1) where compatibility a) of inputs or b) among final products needs to be assured; (2) where there is asymmetric information between producers and consumers about product quality; and (3) in situations where goods are produced or consumed under negative externalities. Case 1 is generally taken care of by the market. Since cases 2 and 3 are situations of market failure, however, government intervention will be necessary.

- Case 1a: Standards are often needed to ensure compatibility between product parts. In cases where firms are vertically integrated, these standards are generally proprietary to the individual firm. However, the logic of splitting the production process vertically and creating competition between the suppliers of inputs would require these standards to be made public. Increased standardization of inputs will benefit the firms which assemble the final products as it serves to thicken supplier markets and thereby depresses prices of inputs. This decrease in margin will hurt incumbents in the input market, yet at the same time, the reduction in entry barriers that is caused by the fact that technology for inputs is no longer proprietary opens the way for new entrants.

- Case 1b: Compatibility between final products is particularly crucial for any kind of network product (such as fax machines or computer software). When a new network product is brought to the market, every firm will want to impose their standard on the entire market, so as to have an initial advantage in terms of production cost. The new common standard can arise either through a standards war or a mutual agreement between firms in the industry (cf. product cycle literature, e.g. Utterbach and Suarez's (1993) notion of "dominant design"). Government should not intervene in this process unless the standard that is imposed on the market is proprietary to an individual firm (because technology is proprietary), which would in certain cases have to raise anti-competitive concerns. 
It should be noted that in both of the above cases, standards are needed for efficiency reasons. Baldwin (2000) calls these horizontal standards. Unless there is a danger of sub-optimal convergence or convergence inertia, the market can be expected to generate optimal common standards and government intervention is hence unwarranted.

Further, cases 2 and 3 describe situations where standards are required in order to correct for market failure. Rather than being just technical specifications, these are minimum quality standards to guarantee the health and safety of the consumer or the protection of the environment - Baldwin (2000) calls these vertical standards. Pelkmans (2003) refers to them as SHEC standards (Safety, Health, Environment and Consumer Protection). These are the types of standards that tend to get the largest public attention, as they are TBTs that can easily be portrayed as protecting local consumers from low-quality imports.

- Case 2 is concerned with asymmetric information about product quality - the case of experience and credence goods. An experience good is defined as a good, the quality of which can be ascertained only after consumption. In the case of a credence good, on the other hand, certain product characteristics may never be revealed to the consumer even after consumption. The market failure in this case is asymmetric information about the true characteristics of the product, including health and safety features. An example for an experience good would be a motorcycle helmet, the true quality of which would only be revealed during an accident. Since the consumer has no possibility of verifying the quality of the product ex ante, government will have to step in and impose minimum standards that guarantee the health and safety of the consumer. An example for a credence good would be bottled water, the true quality of which a consumer will never be able to establish. Again, government intervention is necessary.

- Finally, case 3 deals with goods that are produced or consumed under negative externalities, meaning that there are negative side effects on third parties from the consumption and production of goods which are ignored in the consumption/production decision. Under the assumption of complete information, the most efficient outcome would be reached by imposing an appropriate tax. However, in a second best world, where information is incomplete, setting a minimum/maximum standard might be the optimal solution to solving the externality problem. Often cited examples are maximum levels of lead in petrol or of pesticide residues on agricultural goods.

One can conclude from the above, that standards no matter whether private or public are in all three cases necessary. Both asymmetric information and negative externalities are market failures and hence require government intervention, here in the form of minimum quality standards. These may vary by country depending on the attitude towards risk in a given society. 


\section{Standards as Trade Barriers}

Despite the fact that standards are important in achieving efficiency, their presence can turn out to be an obstacle to trade: while integrating the markets of those who participate, standards can act as a barrier to those who are excluded. In the case of compatibility standards, market forces will act to bring standards in line with those generally prevailing in the market, even though these standards are technically voluntary. Products not meeting these standards may simply not be demanded by firms/consumers as they are incompatible with the other inputs (as in Case 1a) or the prevailing network (as in Case 1b). In the case of government imposed quality standards, on the other hand, compliance is mandatory. In this case the standards are also known as technical regulations. Products not meeting these technical regulations will be banned from the market.

Country-specific standards effectively create additional costs for foreign producers by forcing them to adjust their product and production process so as to meet individual national standards. Further costs will arise from the requirement to subsequently prove conformity with these standards (World Bank TBT Survey, 2004; Baldwin, 2000; Chen and Mattoo, 2004; Wilson, Chen and Otsuki, 2006). This creates two negative side effects: Firstly, foreign producers are hurt by increased (possibly prohibitive) production costs. This may turn out to be particularly burdensome for developing countries trying to get access to industrialized countries' markets. ${ }^{2}$ Second, by creating artificial entry barriers to national markets, standards have a negative effect on efficiency. This is due to the fact that firms which are forced to meet different standards for different markets are unable to take advantage of economies of scale, thereby dampening productive efficiency. As markets remain segmented by standards barriers, firms are further able to raise price over marginal cost, implying less allocative efficiency than could be reached with integrated markets. Even though standards are valuable in and of themselves, these effects have to be taken into account when setting them.

Additionally, Baldwin (2000) points to a "magnification effect of globalization": the greater the freeness of trade, the greater the effect of any remaining barriers especially from an economic geography point of view. In other words, a reduction in distortion arising from tariff barriers, will lead to an increased impact of regulatory differences on the location of production. Finally, such regulations can easily be abused by protectionists to create artificial entry barriers to the domestic market. It is generally difficult to tell, which purpose a particular standard or regulation serves, but there is likely to be an element of both motivations in either. This inherent ambiguity makes it difficult to overcome standards and regulations as technical barriers to trade (TBTs) entirely, but two second-best measures in particular - harmonization and mutual recognition of testing procedures - will be the subject of this paper. The paper will focus on liberalization/harmonization of government-imposed regulations rather than voluntary industry standards.

\footnotetext{
${ }^{2}$ cf. World Bank Survey on TBTs: Wilson and Otsuki (2004) "Standards and Technical Regulations and Firms in Developing Countries: New evidence from a World Bank Technical Barriers to Trade Survey"; find that standards and technical regulations are an important factor affecting a firm's operation and ability to export.
} 
But, yet again, care must be taken that liberalization of these barriers does not happen in a way that results in a disadvantage for the weakest. The way technical barriers to trade are being tackled at the moment, i.e. mainly through agreements between industrialized countries, might mean even more trade diversion away from developing third country producers.

\section{Overcoming TBTs}

Even though standards have been shown to constitute a barrier to trade, they are valuable in and of themselves as argued above. Since removing the standards themselves is therefore not an option, the level playing field will have to be created by accepting their presence and making them compatible. Disciplines imposed by the WTO in this regard are relatively lax due to the fact that the optimal level of health or safety standards depends to a large extent on the level of development of the individual country, so that it is currently impossible to impose common standards for all WTO members. Some provisions in this regard are, however, contained in the Agreements on Technical Barriers to Trade (TBT). ${ }^{3}$

The Preamble to the WTO TBT Agreement states that

"no country should be prevented from taking measures necessary to ensure the quality of its exports, or for the protection of human, animal, and plant life or health, of the environment, or for the prevention of deceptive practices, at the levels it considers appropriate". However, the regulatory flexibility of WTO members is limited by the requirement that technical regulations "are not prepared, adopted or applied with a view to, or with the effect of, creating unnecessary obstacles to trade." (Article 2.2)

In addition, the TBT Agreement sets some basic guidelines in terms of transparency, proportionality ("balancing" requirement, i.e. the measure implemented should be proportional to the desired objective), necessity, and consistency. ${ }^{4}$ These provisions are necessary to prevent governments from hiding protectionist intentions behind SHEC arguments. Even though many of these government imposed standards may be justifiable, the WTO DSB has found in several instances that measures were unnecessarily trade distorting (possibly expressly). ${ }^{5}$

The disciplines imposed by the TBT Agreement are mostly concerned with government imposed standards, though the Agreements also suggest best practice guidelines for the process of standard setting and removal of standards barriers (such as harmonization) both for industry and for government. It should be noted that these are expressly non-binding.

\footnotetext{
${ }^{3}$ Similar provisions can be found in the Agreement on Sanitary and Phytosanitary (SPS) measures, which is concerned with standards aimed at preventing the spread of pests and diseases and ensuring food safety. SPS-related standards are, however, not subject of this paper.

${ }^{4}$ The implications of these conditions are elaborated in various WTO DSB Cases: "balancing": Korea - Various Measures on Beef; necessity requirement: EC Asbestos; consistency: EC Hormones; process and production methods: US - Import Prohibition of Certain Shrimp and Shrimp Products.

${ }^{5}$ Cf. also Deardorff and Stern (1997) on the difficulty of disentangling legitimate measures from protectionist ones.
} 
As argued above, in the case of compatibility of network goods/inputs, standard setting is generally private sector driven, giving rise to voluntary standards regimes that mainly convey information as to what is accepted/expected by the market. "Harmonization" is enforced by the market mechanism: incompatible products are driven out, unless a new standard is so strong as to capture a critical mass of the market. It is worth noting that markets, in this case, cannot be assumed to be confined to national borders. Where industries are global, the market will create international standards. Private sector organizations such as ISO and IEC have been instrumental in driving this process and have created a large number of voluntary international standards over the last decades.

In the case of mandatory safety/health and environmental standards, government action is required for the removal of standard-related barriers. In addition, compliance with internationally agreed mandatory standards will subsequently have to be monitored on a continuous basis (this is done through conformity assessment procedures) and enforced by the individual governments. Since WTO disciplines in this regard are of relatively little stringency (as shown above), more ambitious approaches have been developed in the context of various regional trading arrangements, where it can be assumed that social preferences and constraints are more similar. These initiatives can be grouped as follows:

- Mutual recognition of product standards and technical regulations (if extended unilaterally, referred to as "equivalence" and not to be confused with Mutual Recognition Agreements for conformity assessment procedures): under mutual recognition it is presumed that standards, though varying per se, are designed to meet the same regulatory objectives and there is hence no need for a further agreement. This practice is very common within the European Union and covers approximately $28 \%$ of all products in the EU.

- Harmonization by essential characteristics (the EU's "new approach"): consists of defining essential safety requirements to be fulfilled by a product, but leaving the producer free to design the rest of the product as they see fit. These essential requirements often give rise to voluntary product standards developed by industry, implying that a product which complies with these voluntary standards also fulfils the essential requirements. Producers which do not comply with these standards have to prove in a different way that they comply with the regulation. This method was originally pioneered by the EU and has since then been adopted by AFTA and APEC.

- Harmonization product-by-product (EU's "old approach"): this approach was used by the EU until 1985 and involved tedious product-by-product legislation implemented through numerous detailed directives. Because the high technicality of the process threatened the goal of completing the Single Market by 1992, it was decided to abandon the product-by-product approach in favour of the "essential characteristics approach".

- Compatibility (as used in NAFTA): there does not seem to be a formal definition of this concept in any of the relevant legal texts, yet it seems to imply harmonization of all regulations that are being newly created.

- Acceptance with specific exceptions: a country which has not adopted international standards still has to accept products from partners which comply with these standards, unless they can demonstrate an inability to adopt the 
international standard due to "climatic conditions or infrastructural reasons" (e.g. AFTA).

\section{- Acceptance with broad exceptions (e.g. WTO)}

It should also be noted that the measures listed above are by no means mutually exclusive, but rather often exist alongside each other. It is for example the case for the EU that only $51 \%$ of regulated products are subject to harmonization directives, while the other part of regulated products are subject to the mutual recognition principle (The Single Market Review, EC 1998). Mutual recognition of standards is currently only applied by the EU, as it requires a strong enforcement mechanism (a role that is played by European Court of Justice). Harmonization of standards, on the other hand has been agreed upon in a number of recent preferential agreements, especially those with the EU as one of the partners as well as within AFTA and APEC. In the case of EU agreements, partners are generally asked to harmonize to EU standards (with the exception of EU-Chile and EU-Mexico, which harmonize to international standards), whereas AFTA and APEC ask members to harmonize to international standards. NAFTA members have agreed to make their standards "compatible", which can be interpreted as harmonization, but the principle is only applied to standards that are being newly created.

Besides these arrangements, which aim to overcome barriers posed by standards and technical regulations directly, arrangements concerning conformity assessment procedures (i.e. laboratory testing to see whether a product complies with a given standard or regulation) and mutual recognition thereof have been gaining increasing importance. These types of agreement are less intrusive than direct harmonization in that they do not require countries to change domestic regulations. MRAs for testing procedures are agreements between two or more parties to mutually recognize or accept some or all aspects of one another's conformity assessment results (e.g. test reports and certificates of compliance), thereby avoiding the costs of double testing. ${ }^{6}$ Through MRAs, products that are tested and certified before export can enter the importing country directly without having to undergo similar conformity assessment procedures in the importing country. As opposed to Mutual Recognition of the actual product standards or harmonization thereof, MRAs for testing procedures do not require two trading partners to have comparable SHEC standards per se - they only require the exporter to fulfill the standards of the partner for the product they wish to export, but not meet the same regulatory objectives for their own country. In this sense, MRAs can be seen as a first step towards standards integration and they have indeed become an important tool for trade facilitation.

Testing MRAs can come in two guises: technical and government-to-government (Gto-G). Technical MRAs are concluded between technical bodies (testing laboratories, inspection bodies, certification bodies, accreditation bodies) and while they are nonbinding and therefore not enforceable, they often build the foundation for agreements at the government level. The latter are generally concluded for specific product sectors under government regulation. Examples are MRAs concluded between the EU and third countries (USA, Canada, Australia, New Zealand, Israel, Japan, Switzerland). APEC's Sub-committee on Standards and Conformance (SCSC) is in

${ }^{6}$ Definition from Report of the Taskforce on Developing a Roadmap to Mutual Recognition Agreements in ASEAN; report submitted to $11^{\text {th }}$ meeting of the ACCSQ 11-12 March 1998 
the process of negotiating them for the Asia Pacific region. MRAs can be both bilateral and multi-lateral as well as single- and multi-sector. While APEC MRAs, for example have been single-sector, the EU has generally adopted a multi-sector approach since negotiations of a multi-sector framework are arguably easier, as a rough balance of gains is more easily obtained. Further, G-to-G MRAs can be grouped into 3 different types: i) full harmonization of conformity assessment, ii) equivalence of compliance (a unilateral recognition of compliance), iii) full recognition of conformity assessment (conceptually these are similar to arrangements concerning standards directly - see definitions given in this context above). An example for full harmonization of conformity assessment regulation would be the EU's Single Market framework. Equivalence of compliance is the basis to the TransTasman MRA between Australia and New Zealand, while the bulk of G-to-G MRAs relies on the third category of full recognition of conformity assessment results. The latter means partners are testing and certifying products according to the standards and requirements of the importing country; subsequently, a certificate indicating full compliance with those requirements is issued by the exporting country and must be accepted by the importer. ${ }^{7}-8$

The main concern of the subsequent analysis will be to estimate the impact of regional TBT liberalization, in particular the effects of two specific types of initiative: Mutual Recognition Agreements on testing procedures as well as harmonization of product standards. For all other approaches the degree of implementation is difficult to judge in practice. Legal texts are often vague to the extent that they only recommend certain measures rather than being binding in this respect. The impact of MRAs on trade will be tested only for members of the agreement, while the effects of harmonization will be tested both for members of the liberalizing region as well as excluded countries.

\section{SECTION II}

\section{Literature}

The relationship between standards and trade has only recently started to receive attention from researchers. The main strands of the standards-literature have so far been more concerned with the link between standards and innovation and standards and growth. ${ }^{9}$

Firm level surveys have been conducted, attempting to gauge the direct impact of standards and technical regulations on firms' production costs and hence export performance. The World Bank TBT survey looks at 689 firms in over 20 industries in 17 developing countries (Wilson and Otsuki, 2004). 70\% of these firms report that they face technical regulations in their export markets, whereby EU and US

\footnotetext{
${ }^{7}$ Based on ibid.

${ }^{8}$ For a full list of MRAs and Harmonization initiatives, please refer to Appendix IV and V.

${ }^{9}$ For general overviews of the standardisation literature see Farrell and Saloner (1987), David and Greenstein (1990), Katz and Shapiro (1994) and Matutes and Regibeau (1996); the small part of the literature that is concerned with trade issues is represented by Matutes and Regibeau (1996), Kende (1992), Gandal and Shy (1996), Wallner (1998), Jeanneret and Verdier (1996) and DIN (Deutsches Institut für Normung, 1999); e.g. Blind and Jungmittag (2004), Jungmittag, Blind and Grupp (1999).
} 
regulations are generally considered the most important by the firms surveyed. The study shows that in order to meet standards, firms invest in additional plant or equipment, one-time product redesign, product redesign for each export market, additional labor for production, additional labor for testing and certification, or lay off workers instead of making these types of investment in order to keep the costs from increasing.

Quantitative analysis deriving the trade effect of diverging standards directly from the number or costs of standards has generally proven challenging due to the large number of standards in existence. Additionally, the wealth and idiosyncrasy of legal documents recording them makes it difficult to match standards across countries. Studies conducted in this vein are those by Moenius, 1999; Swann, Temple and Shurmer, 1996; Vancauteren and Weiserbs, 2003; Mantovani \& Vancauteren, 2003. A general weakness of these attempts to estimate the impact of standards on trade is that they are generally not based on a sound theoretical framework.

The attempts of modelling standards barriers and their remedies theoretically are also very limited in number and have been undertaken only very recently. All of them use Krugman's (1980) framework as the basis to model trade between countries, but are very different in the way they are being implemented. One paper that has endeavored to formally model TBTs (yet not their liberalization) and showing the need to overcome them is Ganslandt \& Markusen (2001). Baldwin (2000) as well as Mattoo and Chen (2004) take the analysis a step further by modelling both TBTs and their liberalization, cautioning against the discriminatory effects that the latter may entail. Mattoo and Chen (2004) find that harmonization in the EU raises both intra-regional trade as well as trade with excluded developed countries; at the same time their results indicate that it diverts trade away from developing countries. The paper also shows that MRAs have a more powerful impact on both types of trade, but if they contain rules of origin, then intra-regional trade increases at the expense of imports from the rest of the world, especially developing countries. In a firm level analysis Chen, Wilson and Otsuki (2004) show that testing procedures and lengthy inspection reduce exports of developing countries by $9 \%$ and $3 \%$ respectively and standards reduce the likelihood of exporting to more than three markets by $7 \%$.

\section{SECTION III}

\section{Melitz model and extensions}

Given recent developments in international trade theory, it seems that additional insight into the nature of technical barriers to trade as well as their liberalization can be gained by formulating a model in terms of Melitz's (2003) heterogeneous firms framework. Melitz's model constitutes an improvement over existing trade models to the extent that it is able to explain the many zero entries in the global trade matrix (i.e. the fact that more than half of bilateral country pairs have no trading relationship at all) as well as appropriately reflecting the asymmetry of bilateral trade-flows. Both of these features are obtained via the endogenous selection of individual firms into one or several export markets. Crucially, Melitz points to two margins of adjustment for 
trade flows arising from this selection process. The volume of trade flows will be determined by the volume of exports by each individual exporting firm (the intensive margin) as well as the fraction of firms actually exporting (the extensive margin). The subsequent section will provide a brief introduction to the original model ${ }^{10}$ and develop an extension to the theory so as to formalize regional TBT liberalization initiatives.

As a general set-up for his model, Melitz (2003) uses the framework first introduced by Krugman (1980), in that he assumes a 2-country, 2-good, single factor-ofproduction setting (the only factor being labour). One of the goods is homogeneous and is produced in the A-sector under Walrasian conditions. Trade for this good is costless. The other good is produced in a Dixit-Stiglitz monopolistic competition setting with increasing returns to scale and ice-berg trade $\operatorname{costs}^{11}, \tau \geq 1$. Consumer preferences are represented by a two-tier utility function. The upper tier is CobbDouglas and determines the relative expenditure shares on A- and M-sector goods respectively, while the second tier defines preferences over the differentiated Msector varieties.

$$
U=C_{M}^{\mu} C_{A}^{1-\mu} ; \quad C_{M} \equiv\left(\int_{i=0}^{N} C_{i}^{1-1 / \sigma} d i\right)^{1 /(1-1 / \sigma)}, \quad 0<\mu<1<\sigma
$$

$\mathrm{C}_{\mathrm{M}}$ represents consumption of the composite of all differentiated varieties of goods $M$ and $C_{A}$ is consumption of the homogeneous good $A, \mu$ and $1-\mu$ are the respective expenditure shares, $\mathrm{N}$ is the mass of varieties and $\sigma$ is the constant elasticity of substitution between any two manufactured varieties.

In the M-sector, firms face 4 types of cost: constant marginal cost of production as well as 3 types of fixed cost: $F$ has to be paid in order to acquire a patent for a unique variety so that production is possible at all. Further, market entry costs $F_{D}$ and $F_{X}$ have to be paid for both the domestic and the foreign market respectively. These elements of the model will be of particular relevance for subsequent analysis. We will assume $F_{X}>F_{D}$, where $F_{X}$ can be interpreted as fixed costs arising from adaptation to standards and technical regulations abroad. It should be noted that previous models have considered TBTs to affect both fixed and variable costs. Since the analytical results for variable cost TBTs are straight-forward and the larger part of the costs is hypothesized to come from fixed costs, I will ultimately focus on the effects of changes in fixed costs following regional liberalization.

Variable costs in the domestic and foreign market can be expressed as follows:

$$
\mathrm{c}_{\mathrm{i}} \mathrm{a}_{\mathrm{i}} \mathrm{W} \quad \text { and } \mathrm{c}_{\mathrm{i}}{ }^{*} \mathrm{a}_{\mathrm{i}} \tau \mathrm{w}
$$

where $c_{i}$ are sales in market $i, a_{i}$ is the unit input coefficient (or the firm's level of inefficiency), $w$ is the wage and $\tau$ the ice-berg trade-cost. The model departs from standard new trade theory in that it assumes M-sector firms to be heterogeneous in their productivity levels $a_{i}$. In Melitz's model, each firm draws their own $a_{i}$ from a Pareto distribution (this part of the model is crucial and will be developed further below).

\footnotetext{
${ }^{10}$ Based on Baldwin and Robert-Nicoud (2004)

${ }^{11}$ The concept of iceberg trade costs is due to Samuelson (1954), who modeled transport costs as using up part of the good that is being transported. It is a very convenient way of modeling trade costs as it affects no other market.
} 
The short-run equilibrium where the number and types of firms are fixed is characterized as follows: A-sector results are standard and straight-forward; ultimately, the conditions found in the A-sector ensure that factor-prices are equalized at $\mathrm{w}=\mathrm{w}^{*}=1$. In the M-sector, we will, crucially, see the following: two cut-off levels of $\mathrm{a}_{\mathrm{i}}$ will determine which firms will be producing at all, which will produce only for the domestic market and which will be able also to export, the intuition being that only a sufficiently high level of productivity (i.e. low marginal cost and therefore low price) will generate enough sales so as to cover fixed entry costs for the domestic or domestic as well as foreign market. The cut-off level for exporting firms will be called ax. Any firm with a unit input coefficient below $a_{x}$ will be efficient enough to be able to export. As in the standard Dixit-Stiglitz model, prices of M-sector firms will be a constant mark-up over marginal cost, $a_{i}$ and $a_{i} \tau$ respectively. Prices for the domestic and the export market are therefore given by:

$$
p=\frac{a_{i}}{1-1 / \sigma} \quad \text { and } \quad p^{*}=\frac{\tau a_{i}}{1-1 / \sigma}
$$

In the short-run, the mass of active firms is taken as fixed at $\mathrm{n}$ and the distribution of the $a_{i}$ 's is also given. The productivity distribution can be expressed as the pdf $\rho a_{D}{ }^{-}$ $\rho_{\mathrm{a}^{\rho-1}}$. Operating profits in Dixit-Stiglitz are simply $1 / \sigma$ multiplied by firm-level sales; we can hence write operating profits in the domestic market as

$$
\pi_{\mathrm{j}}^{\mathrm{D}}=\mathrm{B}_{\mathrm{j}} \frac{E}{n \sigma}
$$

where $\mathrm{E}$ is market-specific expenditure on all varieties and $\mathrm{n}$ is the mass of active firms. $B_{j}$ is introduced to simplify notation and captures biases in market shares of individual firms determined by their productivities $\mathrm{a}_{\mathrm{j}}$ : the average operating profit earned by firms is E/n $\sigma$, but firm j's operating profits will be biased depending on firm $j$ 's productivity $a_{j}$ relative to the average productivity a. If written out in its entirety,

$$
\mathrm{B}_{\mathrm{j}}=\frac{a^{1-\sigma}}{\int_{0}^{a D} a^{1-\sigma} g[a] d a+\int_{0}^{a X} a^{1-\sigma} g[a] d a}
$$

The expression in the denominator will later be called $\Delta$ for simplicity. For the export market, operating profits can be written as

$$
\pi_{\mathrm{i}}^{\mathrm{X}}=\phi \mathrm{B}_{\mathrm{j}} \frac{E}{n \sigma}
$$

Total expenditure in a given sector is $\mathrm{E}=\mu \mathrm{L}$, where $\mu$ is the share of income spent on $\mathrm{M}$-sector goods and $\mathrm{L}$ is total labour income, which is the only source of income, since in equilibrium there are no pure profits. As firms have to make fixed cost investments, short-run profits are just sufficient to cover these outlays.

In the Melitz model, the long-run equilibrium is defined as a situation where no pure profits are earned. This condition will pin down the total number of active firms in the $\mathrm{M}$-sector as well as the two productivity cut-off conditions $\mathrm{a}_{\mathrm{D}}$ and $\mathrm{a}_{\mathrm{X}}$.

Since M-sector firms are heterogeneous in the Melitz model, there seems to be the need to model this heterogeneity explicitly. Melitz does so by assuming that every firm wanting to produce a new variety spends a fixed cost $F$ on a patent, not knowing in advance what the productivity level inherent in this patent will be. This is modeled by making the firm randomly draw $\mathrm{a}_{\mathrm{i}}$ from a Pareto distribution, $\mathrm{G}[\mathrm{a}]=\left(\mathrm{a} / \mathrm{a}_{0}\right)^{\gamma}, \gamma$ being the shape parameter of the distribution and $\mathrm{a}_{0}$ the highest possible unit input 
coefficient. ${ }^{12}$ Depending on the level realized, the firm will be able to export, solely supply the domestic market or not produce at all. We can implicitly define the cut-off points for $a_{j}$ via the free entry condition: for the domestic market (from the condition that operating profits equal fixed costs for the least profitable exporter):

$$
\mathrm{a}_{\mathrm{j}}<\mathrm{a}_{\mathrm{D}} ; \quad \frac{a_{D}^{1-\sigma}}{\Delta}\left(\frac{E}{n \sigma}\right)=F_{D}
$$

Similarly, for the export market:

$$
\mathrm{a}_{\mathrm{j}}<\mathrm{a}_{\mathrm{X}} ; \quad \frac{\phi a_{X}^{1-\sigma}}{\Delta}\left(\frac{E}{n \sigma}\right)=F_{X} \quad \text { where } \mathrm{F}_{\mathrm{X}}>\mathrm{F}_{\mathrm{D}}
$$

From this, we can derive the value of an individual patent, which will be equal to operating profits minus market entry costs.

The zero-profit condition in the innovation process on average will determine the equilibrium number of firms in the market. As the number of patents sold (which is equivalent to the number of firms in the market) rises, profits are gradually driven to zero. Ultimately, the long-run number and distribution of firms will be determined by $n$, $\mathrm{a}_{\mathrm{D}}$ and $\mathrm{a}_{\mathrm{X}}$, which in turn arise from the simultaneous solution of the cut-off conditions and the innovation sector's zero-profit condition yielding an equilibrium number of firms of

$$
n=\frac{L / F_{D}}{1+\phi \Gamma}\left(\frac{\mu}{\sigma \lambda}\right) \quad \text { where } 0<\Gamma=\left(\frac{F_{X}}{\phi F_{D}}\right)^{\frac{1-\sigma+\rho}{1-\sigma}}<1
$$

The productivity cut-offs $\mathrm{a}_{\mathrm{D}}$ and $\mathrm{a}_{\mathrm{X}}$ can be written as follows:

$$
\begin{aligned}
& a_{D}=a_{0}\left(\frac{a_{I} / F_{D}}{(2 \lambda-1)(1+\phi \Gamma)}\right)^{1 / \rho} \\
& a_{X}=\frac{a_{0} \phi^{\frac{1}{\sigma-1}}\left(F_{X}\right)^{\frac{-1}{\sigma-1}}\left(F_{D}\right)^{\frac{1-\sigma+\rho}{\rho(\sigma-1)}}\left(a_{I}\right)^{1 / \rho}}{(2 \lambda-1)^{1 / \rho}(1+\phi \Gamma)^{1 / \rho}}
\end{aligned}
$$

Where $a_{I}$ is the cut-off value for profitability of the I-sector, which produces the patents.

In what follows, the paper develops Melitz's model further to formalize TBT liberalization in the form of mutual recognition agreements and harmonization respectively.

It could be argued that mutual recognition agreements of conformity assessment procedures will lead to less of a drop in fixed costs associated with TBTs than harmonization. We could therefore model a regime change as far as MRAs for testing are concerned simply as a drop in $\mathrm{F}_{\mathrm{X}}$ implying less stringent conditions for exporters $-a_{X}$ will rise, while $a_{D}$ will drop due to increased competition from abroad.

\footnotetext{
${ }^{12}$ the use of the Pareto distribution was first introduced by Helpman, Melitz and Yeaple, 2003.
} 
Harmonization might have a more dramatic effect on the equilibrium as the fixed cost reductions will be more tangible. Firms within the harmonizing region will no longer have to comply with every individual standard in the area, but only with a single one. Initial costs of the liberalization might differ, since harmonization generally involves an upward adjustment of standards for participants to the most stringent standard in the region (this was the EU experience, cf. Chen and Mattoo, 2004). However, this complication is left aside for the moment. Harmonization will be modeled as the elimination of $F_{X}$, which implies that firms will now make joint entry decisions for all markets in the region. This will give rise to a new productivity cut-off $a_{s}$ that will intuitively be less stringent than the previous two. The new cut-off point can be derived as follows: the free entry condition will have to be modified in order to reflect the joint entry decision of firms, which, having sunk set-up costs once, can now sell in every country with which technical regulations have been harmonized. We can write:

$$
B_{j} \frac{E}{n \sigma}+(h-1) \phi B_{j} \frac{E^{*}}{n^{*} \sigma^{*}} \geq F_{D}
$$

Where $\mathrm{h}$ is the number of harmonizing countries. For simplicity, we assume that $\mathrm{h}=2$. Replacing the expression for $\mathrm{B}_{\mathrm{j}}$, we can then re-write the equation as:

$$
\frac{a_{j}{ }^{1-\sigma}}{\Delta} \frac{E}{n \sigma}+\phi \frac{a_{j}{ }^{1-\sigma}}{\Delta} \frac{E^{*}}{n^{*} \sigma^{*}} \geq F_{D}
$$

It should be noted, that we no longer have two productivity cut-offs, since firms now face a joint entry decision. Following the logic of the model, they will either not enter at all or enter both markets simultaneously (this analysis assumes away marketing costs and other sunk costs arising from the entry into foreign markets; this seems reasonable for regions, such as the EU, where integration has already progressed to a considerable extent in other areas and where hence knowledge of the foreign market is already good). From the equation above, we can now derive as, the productivity level for which (ii) holds with strict equality. Solving for as yields the following expression (this is derived in detail in Appendix I):

$$
a_{S}=a_{0}\left(\frac{a_{I} / F_{D}}{(2 \lambda-1)}\right)^{1 / \rho}
$$

which implies that $\mathrm{a}_{\mathrm{X}}<\mathrm{a}_{\mathrm{D}}<\mathrm{a}_{\mathrm{S}}$

The result that harmonization will make entry for countries in the harmonizing region less stringent seems obvious. It will be interesting, however to analyze the impact of such initiatives on third countries, in particular whether the impact differs according to the development level of the country in question. As for third countries with competitive industries (i.e. foreign industries that can compete with industries in the harmonizing region despite bearing the adjustment cost to the regional standard) it might be the harmonization of standards within a region that makes joint entry into the newly created, bigger market, profitable, while entry into each individual market before harmonization was not. We should therefore see a positive effect on the probability of entry for both, members of the harmonizing region and competitive third countries. As far as less competitive third countries are concerned, it seems more likely ex-ante that they will suffer a trade reduction. All of the above conjectures are tested below. It should be noted that the formal derivation of third-country effects will be highly complex, as discriminatory liberalization will lead to different productivity cut-offs for different groups of countries. Since the original Melitz (2003) model as it 
stands is already on the edge of analytical tractability, one might have to consider using simulations in order to predict the effects on third-country producers.

\section{SECTION IV}

\section{Empirics}

The main features of the Melitz model (Melitz, 2003) discussed in the previous section and on which the empirical analysis will be based are the following: the representative firm of the classic Krugman (1980) trade model is replaced by a distribution of firms that differ in terms of their individual productivities. Due to the presence of fixed set-up costs, only a fraction of the firms initially participating in a "productivity lottery" will find it profitable to produce for the domestic market and again only a subset thereof will be productive enough to also be able to export, giving rise to asymmetric export patterns among countries. ${ }^{13}$ The fraction of exporting firms from a certain country (the "extensive margin") will crucially depend on the size of the fixed export costs as can be seen from the free-entry condition (equations $7 \mathrm{a}$ and $7 \mathrm{~b}$ above). This feature of the model will allow us to formalize changes in trade patterns due to regional TBT liberalization in the form of MRAs and harmonization.

The empirical analysis is conducted in the framework of the gravity model. The gravity model is an adaptation to economics of Newton's Law of gravity, stating that the volume of trade between two countries depends positively on their economic masses and negatively the distance between them. Taking into account Melitz (2003), the version of the gravity model presented here additionally exploits the fact that not all countries trade with each other and if they do, those trade flows are not necessarily symmetric. These considerations give rise to a two-stage estimation procedure, as derived in Helpman, Melitz, Rubinstein (2004; hereafter HMR), and similar to a Tobit II model. In addition to correcting for Heckman selection bias, HMR use Melitz (2003) to argue that a correction for biases arising from asymmetries in trade flows is also necessary to obtain consistent results. By explicitly including fixed export costs, their specification lends itself to the empirical investigation of technical barriers to trade.

In general, the gravity equation framework has been used to estimate the impact on international trade of

- international borders (McCallum's (1995), Wei (1996), Evans (2003) as well as Anderson and van Wincoop (2003))

- preferential trading blocs (Frankel,1997)

- currency unions (Rose, 2000; Tenreyro and Barro, 2002)

- membership in the WTO (Rose, 2004; Subramanian and Wei, 2004)

- the size of home market effects (Davis and Weinstein, 2003)

This paper will add MRAs of testing procedures and harmonization to the above list of policy initiatives being tested.

\footnotetext{
${ }^{13}$ i.e. if a firm is "unlucky" in the productivity draw, its production costs will be too high to be profitable given the fixed costs it faces in the export market and possibly also in the domestic market.
} 
It has often been criticized that many versions of the gravity equation used to this day lack theoretical underpinnings. Several authors have made attempts to tackle this point of criticism, among them Anderson (1979), Helpman and Krugman (1985), Helpman (1987), Bergstrand (1989, 1990), Deardorff (1998), Feenstra (2002), and Anderson and van Wincoop (2003). However, all of these theories assume positive trade between all trade partners, symmetric bilateral trade flows and the same number of exporting firms across destinations. ${ }^{14}$ Based on Melitz's (2003) theory, HMR's version of the gravity equation, on the other hand, can be seen as a generalization of Anderson and van Wincoop (2003), accounting for firm heterogeneity and fixed trade costs as well as asymmetries in export volumes.

HMR arrive at the following final expression for bilateral trade flows as a function of country characteristics (GDPs: $Y_{i}$ and $Y_{j}$ respectively, price indices: $P_{i}$ and $P_{h}$ ) and variable and fixed cost trade barriers, $\tau_{\mathrm{ij}}$ and $\mathrm{f}_{\mathrm{ij}}$ (the full derivation is presented in the appendix):

$$
M_{i j}=\frac{Y_{i} Y_{j}}{Y} \frac{\left(\frac{\tau_{i j}}{P_{i}}\right)^{1-\varepsilon} V_{i j}}{\sum_{h=1}^{J}\left(\frac{\tau_{h j}}{P_{h}}\right)^{1-\varepsilon} V_{h j} s_{h}}
$$

Where $V_{i j}$ is a proxy for the share of exporting firms and is defined as

$$
V_{j}=\int_{a_{L}}^{a_{i j}} a^{1-\varepsilon} d G(a) \quad \text { for } \mathrm{a}_{\mathrm{ij}} \geq \mathrm{a}_{\mathrm{L}}, 0 \text { otherwise }
$$

For the purpose of this analysis, it should be noted that the fixed export costs are hidden in the $\mathrm{V}_{\mathrm{ij}}$ 's which implicitly contain the level of $\mathrm{f}_{\mathrm{ij}}$ through the productivity cut-offs, a (cf. section III). Equation (1) can then be written in log-linear form as

$$
\mathrm{m}_{\mathrm{ij}}=(\varepsilon-1) \ln \alpha-(\varepsilon-1) \ln \mathrm{c}_{\mathrm{j}}+\mathrm{n}_{\mathrm{j}}+(\varepsilon-1) \mathrm{p}_{\mathrm{i}}+\mathrm{y}_{\mathrm{i}}+(1-\varepsilon) \ln \tau_{\mathrm{ij}}+\mathrm{v}_{\mathrm{ij}}
$$

Lowercase variables represent the natural logarithms of their respective upper case variables, where $\alpha$ determines the elasticity of substitution across products, $\mathrm{Y}_{\mathrm{i}}$ is the income of country $i$ and $P_{i}$ its overall price index, $\mathrm{N}_{\mathrm{j}}$ is the measure (effectively the number) of firms in country $j$ and $c_{j}$ is the cost of country $j$ 's input bundle. Variable trade costs, $\tau_{\mathrm{ij}}$, are assumed to take the form of iceberg trade costs. It is further assumed that these $\tau_{\mathrm{ij}}$ are stochastic due to unobserved i.i.d. country-pair trade frictions, $\mathrm{u}_{\mathrm{ij}} \sim \mathrm{N}\left(0, \sigma_{\mathrm{u}}{ }^{2}\right)$. We can hence write $\tau_{\mathrm{ij}}^{\varepsilon-1} \equiv \mathrm{D}_{\mathrm{ij}}{ }^{\gamma} \mathrm{e}^{-\mathrm{u}_{\mathrm{ij}}}$ where $\mathrm{D}_{\mathrm{ij}}$ is symmetric distance between $\mathrm{i}$ and $\mathrm{j}$. Further, $\mathrm{v}_{\mathrm{ij}}$ is replaced by $\mathrm{w}_{\mathrm{ij}}$, where $\mathrm{w}_{\mathrm{ij}}$ will represent the

\footnotetext{
${ }^{14}$ Recently, some authors have explicitly taken account of the many zero entries in the global bilateral trade matrix and have suggested theoretical interpretations of this phenomenon. Among them are Anderson and van Wincoop (2004), Evenett and Venables (2002) and Haveman and Hummels (2004). Others have focused on the phenomenon of the extensive versus the intensive margin. Eaton and Kortum (2002), for example apply a similar principle to HMR to determine an aggregate gravity equation across heterogeneous Ricardian sectors. As in HMR's model, the predicted trade volume reflects an extensive margin and an intensive one. However, Eaton and Kortum do not model fixed trade costs and the possibility of zero bilateral trade flows. Bernard, Eaton, Jensen and Kortum (2003) use direct information on US plant level sales, productivity, and export status to calibrate a model which is then used to simulate the extensive and intensive margins of bilateral trade flows. Yet, unlike HMR, these papers only accommodate corrections for individual issues raised by HMR, never all.
} 
fraction of firms that export from $\mathrm{i}$ to $\mathrm{j}$. Like $\mathrm{V}_{\mathrm{ij}}, \mathrm{w}_{\mathrm{ij}}$ implicitly contains the level of fixed trade costs, implying that the fraction of exporting firms will depend on $\mathrm{f}_{\mathrm{ij}}$. We hence have:

$$
\mathrm{m}_{\mathrm{ij}}=\beta_{0}+\lambda_{\mathrm{j}}+\chi_{\mathrm{i}}-\gamma \mathrm{d}_{\mathrm{ij}}+\mathrm{w}_{\mathrm{ij}}+\mathrm{u}_{\mathrm{ij}}
$$

where $\chi_{i}=(\varepsilon-1) p_{i}+y_{i}$ is an importer fixed effect and $\lambda_{i}=-(\varepsilon-1) \ln c_{j}+n_{j}$ is an exporter fixed effect. ${ }^{15}$

HMR point out that the exclusion of $\mathrm{w}_{\mathrm{ij}}$ will mean that the effects of trade barriers on firm-level trade would be confounded with their effects on the proportion of exporting firms and $\gamma$ would hence be biased upwards; in order to correct for this, the selection of firms into the export market, $\mathrm{w}_{\mathrm{ij}}$, will have to be estimated itself in a first stage using a probit equation. The related latent variable in this probit estimation will be $\mathrm{z}_{\mathrm{ij}}$ and $\hat{z}_{i j}^{*}=\Phi^{-1}\left(\hat{\rho}_{i j}\right)$. HMR show that $\hat{\bar{W}}_{i j} \equiv \ln \left\{\exp \left[\delta\left(\hat{z}_{i j}^{*}+\hat{\bar{\eta}}_{i j}^{*}\right)\right]-1\right\}$ is a consistent estimate for $\mathrm{E}\left[\mathrm{w}_{\mathrm{ij} \mid}{ }^{\prime}, \mathrm{T}_{\mathrm{ij}}=1\right]$. This will correct for unobserved firm-level heterogeneity. There is further the need to correct for Heckman selection bias using the inverse Mills ratio, here expressed as $\hat{\bar{\eta}}_{i j}^{*}=\phi\left(\hat{z}_{i j}^{*}\right) / \Phi\left(\hat{z}_{i j}^{*}\right)$.

All of the above implies that we can estimate (3) consistently by transforming it into

$$
m_{i j}=\beta_{0}+\lambda_{j}+\chi_{i}-\gamma d_{i j}+\ln \left\{\exp \left[\delta\left(\hat{z}_{i j}^{*}+\hat{\bar{\eta}}_{i j}^{*}\right)\right]-1\right\}+\beta_{u \eta} \hat{\bar{\eta}}_{i j}^{*}+e_{i j}
$$

where $\beta_{\mathrm{u \eta}} \equiv \operatorname{corr}\left(\mathrm{u}_{\mathrm{ij}}, \eta_{\mathrm{ij}}\right)\left(\sigma_{\mathrm{u}} / \sigma_{\eta}\right)$ and $\mathrm{e}_{\mathrm{ij}}$ is an i.i.d. normally distributed error term.

Since $\mathrm{w}_{\mathrm{ij}}$ (and hence $\mathrm{z}_{\mathrm{ij}}$ ) implicitly hinges on the fixed costs faced by firms in their export markets, fixed cost barriers should turn out to be significant in the probit stage of the equation, whereas variable cost barriers are expected to turn out significant in the second stage. As many trade barriers impose both fixed and variable costs at the same time, it is hypothesized that the variables important in the probit stage of the estimation, i.e. those influencing the export decision of a firm, will be similar to those determining export volumes in the actual gravity estimation. It seems likely that harmonization initiatives and mutual recognition agreements affect both fixed and variable costs (Baldwin, 2000; Mattoo and Chen, 2004).

In order to satisfy the exclusion restriction for identification of the second stage of the estimation, the set of variables in the first and second stages cannot be exactly the same. It will therefore be important to identify a trade barrier that affects purely the fixed cost of exporting, such that it can be dropped from the second stage of the estimation.

For the purpose of estimation, dummies will be introduced for mutual recognition agreements and harmonization initiatives initially in both stages. Speculations as to their signs will be discussed below. The following specification will be used (see Table 1 for variable definitions):

\footnotetext{
${ }^{15}$ HMR (2006) show that consistency requires the use of separate country fixed effects for exporters and importers as proposed by Feenstra (2002).
} 


\section{Stage 1 (probit):}

$$
\begin{aligned}
& \rho_{\mathrm{ij}}=\operatorname{PR}\left(\mathrm{T}_{\mathrm{i}, \mathrm{j}}=1 \text { observed variables }\right)=\alpha_{\mathrm{i}}+\alpha_{\mathrm{j}}+\alpha_{\mathrm{t}}+\beta_{1} \text { lngdprep }+\beta_{2} \\
& \text { lngdppcrep }+\beta_{3} \text { lngdppar }+\beta_{4} \text { lngdppcpar }+\beta_{5} \text { lndistwces }+\beta_{6} \text { contig }+\beta_{7} \\
& \text { comlang_off }+\beta_{8} \text { colony }+\beta_{9} \text { lleither }+\beta_{10} \text { isleither }+\beta_{11} \text { wto }+\beta_{12} \mathrm{fta}+\beta_{13} \\
& \text { mra(sector } \left.)+\beta_{14} \text { hr(sector }\right)+\beta_{15} \text { hr(sector)oecd_sgp }+\beta_{16} \text { hr(sector)_dev }+ \\
& \mathrm{u}_{\mathrm{ij}}
\end{aligned}
$$

Before turning to the second stage of the estimation, it will be helpful to relax two assumptions made in the original model. HMR show that results do not depend on the assumption of a Pareto distribution of firm-level productivities. By making $\mathrm{v}_{\mathrm{ij}}$ an arbitrary increasing function of $z_{\mathrm{ij}}$, they eliminate the non-linearity in $\hat{\bar{w}}_{i j}^{*}$ and thereby the need to estimate the second stage by maximum likelihood. Instead, stage 2 can be estimated by OLS. They further drop the normality assumption for the unobserved trade costs (which was needed to recover the $\hat{\bar{Z}}_{i j}^{*}$ and $\hat{\bar{\eta}}_{i j}^{*}$ ) and work instead directly with the predicted probabilities $\hat{\rho}_{i j}$. The actual gravity equation looks as follows:

\section{Stage 2 (OLS):}

$$
\begin{aligned}
& \ln (\text { sector }) \exp =\alpha_{\mathrm{i}}+\alpha_{\mathrm{j}}+\alpha_{\mathrm{t}}+\beta_{1} \text { lngdprep }+\beta_{2} \text { lngdppcrep }+\beta_{3} \text { lngdppar }+\beta_{4} \\
& \text { lngdppcpar }+\beta_{5} \text { lndistwces }+\beta_{6} \text { contig }+\beta_{7} \text { comlang_off }+\beta_{8} \text { colony }+\beta_{9} \\
& \text { lleither }+\beta_{10} \text { isleither }+\beta_{12} \text { fta }+\beta_{13} \operatorname{mra}(\text { sector })+\beta_{14} \operatorname{hr}(\text { sector })+\beta_{15} \\
& \operatorname{hr}\left(\text { sector)oecd_sgp }+\beta_{16} \operatorname{hr}(\text { sector }) \text { dev }+\hat{\rho}_{i j}+\hat{\bar{\eta}}_{i j}^{*}+\mathrm{e}_{\mathrm{ij}}\right.
\end{aligned}
$$

The predictions as to the direction of effects of individual variables are very similar for the two stages. Yet the interpretation is different to the extent that the first stage explains the impact on the probability that a certain firm is going to export (the extensive margin), while the second stage explains the increase in bilateral trade volume for firms already exporting before the liberalization took place (the intensive margin).

As for the variables of interest, some preliminary comments seem to be in order at this point. As far as MRAs are concerned, only effects on parties to the agreement were investigated. Third party effects are difficult to evaluate in this case, as some agreements are subject to rules of origin while others are not. In the latter case, MRAs should have a similarly positive effect on competitive third country producers as harmonization, while in the former case markets remain segmented for countries outside the liberalizing region. It could not always be established from the available documentation whether rules of origin were in place, so no analysis of the effect on third countries was conducted. For harmonization, on the other hand, these effects were taken into account. Hence, two further dummies were introduced to this effect, which take on the value "one" if the exporter is a developing country and the importer is member of a harmonizing region, or respectively, if the exporter is in the $\mathrm{OECD}^{16}$, but not harmonizing, while the importer is.

\footnotetext{
${ }^{16}$ For the purpose of the analysis Singapore was included in this group
} 
Table 1: Variable definitions

Dependent variables:

- $\quad$ Stage 1: pr(sector)exp: binary; indicates whether there were positive export flows between a country-pair for a given year in a given sector

- $\quad$ Stage 2: $\ln ($ sector)exp: log of export flows between a country-pair for a given year in a given sector

Explanatory variables:

- Ingdprep: log exporter GDP in constant (2000) US\$

- $\quad$ lngdppcrep: log exporter GDP per capita in constant (2000) US\$

- $\quad$ lngdppar: log importer GDP in constant (2000) US\$

- lngdppcpar: log exporter GDP per capita in constant (2000) US\$

- Indistwces: log of distance between countries weighted by the geographic distribution of population

- contig: 0-1 dummy that indicates whether countries share a common border

- comlang_off: 0-1 dummy that indicates whether countries share a common official language

- colony: indicates whether countries have had a colonial link at some point in their history

- lleither: 0-1 dummy that indicates whether either of the countries is landlocked

- isleither: 0-1 dummy that indicates whether either of the countries is an island

- wto: 0-1 dummy that indicates whether both countries are members of the GATT/WTO at a given point in time

- fta: 0-1 dummy that indicates whether both countries are members of the same FTA at a given point in time

- mra(sector): 0-1 dummy that indicates whether both countries have an MRA with each other at a given point in time

- $\operatorname{hr}($ sector ): 0-1 dummy that indicates whether both countries have harmonised standards at a given point in time

- $\quad$ hr(sector)oecd_sgp: 0-1 dummy that takes the value 1 if the exporter is an OECD country (or Singapore) that is not part of a harmonising region, while the importer is part of such a region

- $\operatorname{hr}($ sector)_dev: 0-1 dummy that takes the value 1 if the exporter is a non-OECD country that is not part of a harmonising region, while the importer is part of such a region

- $\quad a_{i}$ and $a_{j}$ are importer and exporter fixed effects respectively as used in HMR 2004. In the course of the analysis the validity of using country-pair direction-specific fixed effects, $\mathrm{a}_{\mathrm{ij}}$ will also be investigated

- $\mathrm{a}_{\mathrm{t}}$ is a time trend, capturing unspecified effects of the phenomenon of "globalization"

As for the coefficients on the variables of interest, it is hypothesised that having an MRA or being part of a harmonising region will increase the probability of two countries trading with each other. If there were high volumes of trade between two partners already before liberalization, the export-probability might not increase any further, so the coefficient could also turn out to be zero. In the case of harmonization, we also need to make predictions about the effects on excluded countries. For them, the effect is expected to be more ambiguous. Two forces will be working in opposite directions: while a common standard will give firms in partner-countries a costadvantage, thereby possibly acting trade-reducing for third countries, it might be the newly integrated market that makes it worthwhile for third countries to export to the region in the first place. It is expected that the market integration effect will prevail over the cost-disadvantage effect for third countries with competitive export sectors in the industries under consideration. The effect for less competitive third countries (in this study the non-OECD countries) is expected to be less positive than that for the more competitive ones, yet a prediction about the sign of the coefficient seems difficult. Regarding the second stage of the estimation, it is expected that MRAs contribute to a firm's variable cost and should therefore turn out to be significant. Since harmonization, on the other hand, is hypothesized to remove mainly fixed costs, those liberalization dummies should turn out to be insignificant in the second stage. 


\section{SECTION V}

\section{Data}

The time period under consideration is 1986 to 2003. This is motivated by the fact that the EU's Old Approach to harmonization was phased out in 1985, while the first harmonization directive investigated in this paper was passed in 1990. MRAs were mostly implemented in the late 1990s/early 2000s. The sample of countries includes all OECD countries for which complete data was available as well as the top 22 manufacture exporting non-OECD countries. ${ }^{17}$ The Czech Republic, Poland, Kuwait, and Taiwan were dropped due to insufficient GDP data. In total, the sample consists of 2256 country pairs $(48 * 47)$ across 18 years.

Bilateral trade data at the 3-digit level (SITC Rev.2) was obtained from the UN's COMTRADE database. As is standard for analysis of trade flows, bilateral import data was obtained and subsequently converted into bilateral export flows. GDP and population data is from the World Bank's WDI database, while contiguity, language, colonial and distance variables were obtained from the website of the CEPII. For geographical information, the CIA factbook was consulted. GATT/WTO membership and accession dates are as given on the WTO website. FTAs are those included by Rose (2003). Information on membership in MRAs and harmonization initiatives was obtained from various websites. ${ }^{18}$

\section{Implementation}

The empirical analysis is conducted at the sectoral level. The two sectors being analyzed are telecommunications equipment (sample from 1991-2003) and medical devices (sample from 1986-2003) as their coverage by MRAs and harmonization seems widest. The sample contains 8 MRAs on medical devices and 14 on telecommunications equipment. By the end of the sample period, harmonization in the two chosen sectors had been undertaken only among EU members (in medical devices and telecoms equipment) and ASEAN members (in telecoms equipment).

For medical devices, two separate regressions were run in order to account for possibly differing effects of the 1990 and 1993 harmonization directives, which covered active implantable and general medical devices respectively. Impact is expected to be slightly different between sectors due to the differing nature of the standard involved. While the telecommunications standards under investigation were designed to ensure compatibility ${ }^{19}$, standards for medical devices were set to ensure a

\footnotetext{
${ }^{17}$ For an exact list please refer to appendix III. Non-OECD countries in the sample are the top 22 countries in the competitive industrial performance (CIP) index published by UNIDO in its 2004 Industrial Development Report. The sample was restricted to only the most competitive developing countries as for others restrictions of manufacturing exports do not necessarily apply. Further, Krugman's (1980) model which assumes Dixit-Stiglitz monopolistic competition and on which also Melitz (2003) is based only allows for intra-industry trade, whereas trade between OECD countries and LDCs is mostly inter-industry

${ }^{18}$ For a list of initiatives, please refer to appendix IV and V.

${ }^{19}$ In this case, it seems that industry was not able to generate a common standard, such that government intervention was necessary
} 
certain quality level. Telecoms trade is therefore expected to increase more as products become more substitutable in the wake of harmonization, thereby making it possible to use equipment from foreign producers. In the case of medical devices, demand for products from abroad may actually fall as quality levels are raised to the same standard in all countries.

A fixed effects probit estimation in the first stage combined with a fixed effects OLS estimation (corrected for Heckman selection bias and firm heterogeneity bias) in the second stage was implemented. Two versions of this model were run: one with separate exporter-, importer- and year-fixed effects and another with country-pair and year fixed effects.

Which of the two is the more appropriate one, will depend on one's theoretical assumptions about the trading relationship. ${ }^{20}$ The country-pair dummy approach was implemented in the course of the analysis, though the results obtained seem to suggest that separating out exporter- and importer-fixed effects is more appropriate for the specification estimated here. Results for the country-pair approach are therefore only presented in the appendix. ${ }^{21}$ In the specification being estimated, country-pair fixed effects will not capture reality as well as individual importer and exporter fixed effects. When estimating the impact of TBT liberalization initiatives at the sectoral level, it seems likely that country characteristics (i.e. idiosyncrasies in the regulatory environment of a country or "hidden technology") will be more important in explaining trade flows than characteristics that are specific to the country pair. These idiosyncrasies are expected to be particularly pronounced in the case of trade in medical devices as health systems vary dramatically from country to country. Also for telecoms, being subject to different regulations in different countries, the countryfixed effect is expected to be more important than any country-pair fixed effects. Results obtained from the specification with separate exporter- and importer fixed effects are discussed below.

\footnotetext{
${ }^{20}$ Cheng and Wall (2005) show that unless economic theory points into a different direction, countrypair specific fixed effects should be used. The intuition behind this approach is that we might be looking for an omitted third factor that is common to a country-pair and that would induce the formation of a preferential trading relationship. It seems highly likely that the probability of two countries trading with each other as well as the actual trade volume between them is influenced by factors that are idiosyncratic to the country pair, such as special political interests, history and geography. This heterogeneity can be captured by introducing country-pair specific dummies, separately for each direction of trade. In this case, time-invariant country-pair specific factors like distance, colonial ties, common language etc. are subsumed into the fixed effects and must thus be dropped from the regression.

${ }^{21}$ If one were to further extend the specification to include time-varying country-pair specific fixed effects, one were to take full account of Anderson and van Wincoop's (2003) critique in capturing what they call multilateral resistance terms. It should be noted, however, that the time-varying country-pair fixed effects cannot be annual if the data is, as in this case all degrees of freedom would be used up.
} 


\section{SECTION VI}

\section{Results}

(see Appendix VI for detailed regression results)

\section{Stage 1}

The results from the probit estimation show that both mutual recognition agreements and harmonization of technical regulations have a significant impact on the selection of firms into export markets. Coefficients on the MRA variable are large, positive and significant at the 1\% level for both telecoms and medical devices (1990 and 1993). It is worth noting that the coefficients on the telecoms MRA dummies are larger than the respective coefficients on WTO membership and in the case of telecoms MRAs more than twice as big as the coefficient on FTA membership. For medical devices, the coefficients on MRA and FTA are of comparable magnitude. The result that MRAs for telecoms and medical devices turn out to be significant, is also interesting in light of the fact that implementation of MRAs cannot be taken for granted. Results obtained here suggest that MRAs in the two sectors are indeed being implemented.

Coefficients on the harmonization dummy are insignificant (for medical devices) or negative and significant at the $10 \%$ level (for telecoms), which would suggest that no extra firms enter the market of a partner country after harmonization has taken place. This could be explained by the fact that countries which implement harmonization directives, generally already have very close trading relationships, such that the probability of their trading with each other cannot increase any further. As for excluded countries, the results indicate that export decisions of excluded OECD countries are affected in a positive way and strongly so. This would suggest that the market integration effect by far outweighs any cost disadvantages that arise from having to adjust one's product to a foreign standard in the case of competitive third country producers. This effect can be expected to be particularly strong after a large group of countries such as the EU harmonize standards. According to the results obtained here, developing countries do not see such positive effects on their exports to a harmonizing region.

Using the cost interpretation for the first stage, results seem to indicate that conformity assessment procedures add a considerable amount of fixed costs for producers. Diverging national technical regulations, on the other hand, seem to be imposing fixed costs mainly on competitive third country producers. This is in line with the hypothesis by Chen and Mattoo (2004) that more advanced countries tend to cope with different national standards by redesigning the product, whereas developing countries tend to employ more labour instead, which would affect variable rather than fixed cost. ${ }^{22}$

\section{Stage 2}

In order to ensure identification of the second stage, the WTO variable was dropped from the system, after it was established that WTO membership is only significant in the selection equation of the model. Heckman selection bias was corrected for by

\footnotetext{
${ }^{22}$ Cf. also World Bank (2004) Technical Barrier to Trade Survey.
} 
using the Heckman two-step procedure and the probabilities estimated in stage one of the specification were introduced as correction for biases from firm heterogeneity.

Results suggest that MRAs have no effect on the volume of bilateral exports in the telecoms sector, though they significantly increase trade in medical devices, implying that conformity assessments impose significant variable costs on producers of medical devices. The effect of harmonization on partner countries is negative and significant for both industries. Industry research (EC 2005, Medical Device Sector competitiveness study) shows an increase in intra-EU trade flows of medical devices around 1994, one year after the second harmonization initiative. However, extra-EU, US and Japanese medical device exports and imports pick up at the same time, suggesting an overall increase in demand, rather than a direct reaction to harmonization. The increase in trade volumes may therefore be picked up in the time fixed effects. The seemingly weak reaction to the 1990 and 1993 directives could be explained by the fact that harmonization completed product market integration: since firms lose their ability to price discriminate as soon as markets are no longer segmented, TBT liberalization must not necessarily lead to more trade, but could instead even cause a drop in trade volumes (Brander and Krugman, 1983). Ultimately, it would be interesting to see whether prices of partner countries converged after harmonization.

It should also be noted that the sample includes only two harmonizing regions, the EU and ASEAN, whereby ASEAN's harmonization efforts are very recent such that effects may not fully show until after the end of the sample period. Once more years will become available for ASEAN it will also be interesting to compare the effects on third countries of EU harmonization to regional standards with ASEAN harmonization to international standards.

Effects from harmonization on excluded countries are either positive or negligible. Harmonization seems to have no important effect on the intensive margin of telecoms equipment or medical devices traded for competitive producers. For developing country exports, the coefficient on third-party harmonization is significantly positive for telecoms while those for medical devices also turn out to be insignificant.

\section{SECTION VII}

\section{Policy Implications}

Overall, the picture emerges that TBT liberalization initiatives have been very effective. MRAs and harmonization are shown to affect firms' decisions to enter new markets more strongly than the export volumes of those already exporting. The recent export promotion literature increasingly recommends focusing measures on encouraging more firms to export rather than encouraging current exporters to export more. The results obtained in this paper suggest that MRAs could be a supportive policy instrument in this process. 
The analysis also shows that firms in developing countries are generally not in a position to take advantage of such reductions in fixed export costs. They are seldom partners to MRAs or fully implemented harmonization initiatives and also do not seem to be benefiting from the market integrating effects of harmonization in other regions. One reason for their absence from international standards agreements is that the type of integration described in this paper relies heavily on enforcement by the individual member countries, for which institutions and capacities are often lacking in developing countries. Industrialized countries have therefore been reluctant to negotiate MRAs or harmonization agreements with developing countries.

Developing countries could follow a gradual approach to remedy this situation, first building the laboratory and accreditation infrastructure to facilitate MRAs. Since MRAs for testing procedures only apply to the export sector, their enforcement will be less costly than the enforcement of a certain harmonized standard in an entire sector. Support and technical assistance from industrialized countries in this respect has been forthcoming and it is important that this continues to encourage MRAs between developing and industrialized countries as well as among developing countries. Deeper forms of integration such as the actual harmonization of product standards could follow at a later stage.

\section{Conclusions}

This paper contributes to the existing literature on TBT liberalization in several ways. Most empirical papers on the topic to date have lacked sound theoretical underpinnings. This paper attempts to correct this by using recent trade theory and the empirical framework linked to it and developing the model to accommodate the issue at hand. It looks at trade effects from TBT liberalization for members of the liberalizing region as well as two separate groups of excluded countries, industrialized and developing respectively. In order to conduct a meaningful analysis a dataset of more than 40,000 observations was compiled and the most recent econometric research was taken into account.

The study finds compelling evidence that Mutual Recognition Agreements for testing procedures have a strong impact on both export probabilities and bilateral trade volumes. The evidence is less compelling for harmonization. In the case of harmonization, three cases need to be considered: the effect on parties to the harmonization agreement, on industrialized third parties and on developing third parties. The harmonization variable for partners is systematically insignificant or negative across specifications and stages which seem puzzling at first, yet economic justifications are presented above. For excluded countries, results are very much in line with theory. The order of the effect is mostly consistent across specifications, the effect on industrialized countries generally being more positive than that on developing countries. Results for changes in developing country trade flows are mixed, being positively significant only for telecoms in the second stage and negligible for others. In general, results are robust across different time periods and sectors. 
Further, the first stage of the gravity estimation seems to confirm the theoretical conjecture that foreign standards and technical regulations as well as the testing procedures connected to them represent mostly fixed cost for OECD firms while they seem to affect variable costs for firms from developing countries, at least in the telecoms sector.

In terms of future research, it will be interesting to differentiate between harmonization to an international standard vs. harmonization to a regional standard as well as account for the effects of the introduction of suppliers' declaration of conformity. 


\section{Appendix I - Derivation of as}

Starting from the free entry condition, we have for firm $\mathrm{j}$ :

$$
\frac{a_{j}{ }^{1-\sigma}}{\Delta} \frac{E}{n \sigma}+\phi \frac{a_{j}{ }^{1-\sigma}}{\Delta} \frac{E^{*}}{n^{*} \sigma^{*}} \geq F_{D}
$$

Assuming symmetric countries, we can rewrite this condition for the borderline firm as:

$$
\frac{a_{S}{ }^{1-\sigma}}{\Delta}(1+\phi) \frac{E}{n \sigma}=F_{D}
$$

As far as the innovation sector is concerned, the auctioned patents will command the following prices:

$$
\begin{array}{ll}
F[a]=0 & \text { if } \mathrm{a}_{\mathrm{S}}<\mathrm{a}_{\mathrm{j}}<\mathrm{a}_{0} \\
F[a]=\frac{\left(a_{j} / a_{S}\right)^{1-\sigma}}{\Delta}(1+\phi) \frac{E}{n \sigma}-F_{D} \quad \text { if } \mathrm{a}_{\mathrm{j}} \leq \mathrm{a}_{\mathrm{S}}
\end{array}
$$

$\mathrm{B}_{\mathrm{j}}$ in terms of firm $\mathrm{j}$ 's relative competitiveness can be written as follows:

Further, the innovation sector's zero profit condition is:

$$
\left(\frac{a_{S}}{a_{0}}\right)^{\rho}\left(\frac{2 E}{n \sigma}-F_{D}\right)=a_{I}
$$

Combining the income equation $\mathrm{E}=\mu \mathrm{L}$

With the free entry condition $\frac{a_{S}{ }^{1-\sigma}}{\Delta}(1+\phi) \frac{E}{n \sigma}=F_{D}$

And recalling the definition of delta: $\Delta=\lambda \mathrm{a}_{\mathrm{S}}{ }^{1-\sigma}(1+\phi)$

We can derive the equilibrium number of firms in the long-run

$$
\frac{a_{S}^{1-\sigma}}{\lambda a_{S}^{1-\sigma}(1+\phi)} \frac{\mu L}{n \sigma}=F_{D}
$$




$$
\begin{aligned}
& \frac{\mu L}{\lambda(1+\phi) n \sigma}=F_{D} \\
& \left(\frac{\mu}{\sigma \lambda}\right)\left(\frac{L}{n(1+\phi)}\right)=F_{D} \\
& \left(\frac{\mu}{\sigma \lambda}\right)\left(\frac{L / F_{D}}{(1+\phi}\right)=n
\end{aligned}
$$

Further, we can write $B_{j}$ for $a_{j}=a_{s}$ as

$$
B_{j}=\frac{1}{\lambda(1+\phi)}
$$

Yielding

$$
\pi^{e}=\frac{2 E}{n \sigma} \quad \Rightarrow \quad \frac{\pi^{e}}{2}=\frac{E}{n \sigma}
$$

From (7), we can therefore write

$$
\begin{aligned}
& \frac{a_{S}^{1-\sigma}}{\Delta}(1+\phi) \frac{\pi^{e}}{2}=F_{D} \\
& \frac{a_{S}^{1-\sigma}}{\Delta}(1+\phi) \pi^{e}=2 F_{D} \\
& \pi^{e}=\frac{2 F_{D}}{\frac{a_{S}^{1-\sigma}}{\Delta}(1+\phi)}=\frac{2 F_{D}}{B_{j}(1+\phi)}
\end{aligned}
$$

Substituting $B_{\mathrm{j}}$ into (13c) yields $\pi^{e}=2 \lambda F_{D}$

The ratio of firms that pay $F_{S}=1$, so $f^{e}=F_{D}$

Hence, $\pi^{e}-f^{e}=2 \lambda F_{D}-F_{D}=F_{D}(2 \lambda-1)$

Re-arranging (6), then gives: 


$$
\begin{aligned}
& \left(\frac{a_{S}}{a_{0}}\right)^{\rho}\left(F_{D}(2 \lambda-1)\right)=a_{I} \\
& \frac{a_{S}}{a_{0}}=\left(\frac{a_{I}}{F_{D}(2 \lambda-1)}\right)^{1 / \rho}
\end{aligned}
$$

Yielding the final expression for $\mathrm{a}_{\mathrm{S}}$

$$
a_{S}=a_{0}\left(\frac{a_{I} / F_{D}}{(2 \lambda-1)}\right)^{1 / \rho}
$$




\section{APPENDIX II - Derivation of the empirical specification following HMR, 2004}

The basic set-up of the model is that of Krugman (1980), where the demand side is represented by CES preferences of the form

$$
u_{j}=\left[\int_{l} x_{j}(l)^{\alpha} d l\right]^{1 / \alpha} \quad 0<\alpha<1
$$

With demand given by

$$
\begin{aligned}
& x_{j}=\frac{\hat{p}_{j}(l)^{-\varepsilon} Y_{j}}{P_{j}^{1-\varepsilon}} \quad \text { where } \mathrm{p}_{\mathrm{j}}(1) \text { is the price of product } 1 \text { in country } \mathrm{j} \text { and } \\
& P_{j}=\left[\int_{l \in B_{j}} \hat{p}_{j}(l)^{1-\varepsilon} d l\right]^{1 /(1-\varepsilon)} \quad \text { is the country's ideal price index }
\end{aligned}
$$

Prices are a constant mark-up over marginal cost due to the assumption of Dixit-Stiglitz monopolistic competition, so a firm with productivity level a, will charge the mill price of:

$$
p_{j}(a)=\frac{1}{\alpha} c_{j} a
$$

Firms face two types of export costs, iceberg trade costs $\tau_{\mathrm{ij}}>1$ as well as fixed trade costs $f_{\mathrm{ij}}>$ 0 measured in units of labour, whereby the latter can be thought of as representing technical barriers to trade. A firm that exports from $\mathrm{i}$ to $\mathrm{j}$, has export sales and profits (earned in $\mathrm{j}$ )

$$
\begin{aligned}
& r_{i j}(a)=\left(\frac{\tau_{i j} c_{j} a}{\alpha P_{i}}\right)^{1-\varepsilon} Y_{i} \\
& \pi_{i j}(a)=(1-\alpha)\left(\frac{\tau_{i j} c_{j} a}{\alpha P_{i}}\right)^{1-\varepsilon} Y_{i}-c_{j} f_{i j} \quad \text { where } Y_{\mathrm{i}} \text { is aggregate y of importer } \mathrm{i}
\end{aligned}
$$

The cut-off level of profitability is implicitly characterized by the condition that the least productive exporting firm will just break even, i.e. for this borderline firm operating profits will equal fixed costs exactly:

$$
(1-\alpha)\left(\frac{\tau_{i j} c_{j} a}{\alpha P_{i}}\right)^{1-\varepsilon} Y_{i}=c_{j} f_{i j}
$$

Bilateral trade volumes can then be characterized as follows:

Let $\quad V_{j}=\int_{a_{L}}^{a_{i j}} a^{1-\varepsilon} d G(a) \quad$ for $\mathrm{a}_{\mathrm{ij}} \geq \mathrm{a}_{\mathrm{L}}, 0$ otherwise (= proxy for the share of exporting firms)

We can then derive the value of country i's imports from $\mathrm{j}$ given the demand function and the pricing equation as 


$$
\begin{aligned}
M_{i j} & =N_{j} \int_{a_{L}}^{a_{i j}} r_{i j}(a) d G(a) \\
& =\left(\frac{c_{j} \tau_{i j}}{\alpha P_{i}}\right)^{1-\varepsilon} Y_{i} N_{j} V_{i j}
\end{aligned}
$$

Together with the export cut-off condition

$$
(1-\alpha)\left(\frac{\tau_{i j} c_{j} a}{\alpha P_{i}}\right)^{1-\varepsilon} Y_{i}=c_{j} f_{i j}
$$

HMR, arrive at the following final expression for bilateral trade flows as a function of country characteristics and trade barriers $\tau_{\mathrm{ij}}$ and $\mathrm{f}_{\mathrm{ij}}$ :

$$
M_{i j}=\frac{Y_{i} Y_{j}}{Y} \frac{\left(\frac{\tau_{i j}}{P_{i}}\right)^{1-\varepsilon} V_{i j}}{\sum_{h=1}^{J}\left(\frac{\tau_{h j}}{P_{h}}\right)^{1-\varepsilon} V_{h j} s_{h}}
$$


APPENDIX III - Countries included in the Sample

\begin{tabular}{|c|c|}
\hline COUNTRY & COUNTRY CODE \\
\hline Argentina & $\mathrm{ARG}$ \\
\hline Australia & AUS \\
\hline Austria & AUT \\
\hline Belgium-Luxemburg & BLX \\
\hline Brazil & BRA \\
\hline Barbados & BRB \\
\hline Canada & CAN \\
\hline Switzerland & CHE \\
\hline China & $\mathrm{CHN}$ \\
\hline Costa Rica & CRI \\
\hline Germany & DEU \\
\hline Denmark & DNK \\
\hline Egypt & EGY \\
\hline Spain & ESP \\
\hline Finland & FIN \\
\hline France & FRA \\
\hline UK & GBR \\
\hline Greece & GRC \\
\hline Hong Kong & HKG \\
\hline Hungary & HUN \\
\hline Indonesia & IDN \\
\hline India & IND \\
\hline Ireland & IRL \\
\hline Iceland & ISL \\
\hline Israel & ISR \\
\hline Italy & ITA \\
\hline Jordan & JOR \\
\hline Japan & JPN \\
\hline Korea & KOR \\
\hline Mexico & MEX \\
\hline Mauritius & MUS \\
\hline Malaysia & MYS \\
\hline Netherlands & NLD \\
\hline Norway & NOR \\
\hline New Zealand & NZL \\
\hline Pakistan & PAK \\
\hline Philippines & PHL \\
\hline Portugal & PRT \\
\hline Singapore & SGP \\
\hline El Salvador & SLV \\
\hline Slovak Republic & SVK \\
\hline Sweden & SWE \\
\hline Thailand & THA \\
\hline Tunisia & TUN \\
\hline Turkey & TUR \\
\hline Uruguay & URY \\
\hline USA & USA \\
\hline South Africa & ZAF \\
\hline
\end{tabular}




\section{Appendix IV - Mutual Recognition Agreements}

\begin{tabular}{|c|c|c|}
\hline MRA PARTNERS & $\begin{array}{l}\text { YEAR OF ENTRY } \\
\text { INTO FORCE }\end{array}$ & SECTORS COVERED \\
\hline EU - AUS & 1998 & $\begin{array}{l}\text { Medicinal products } \\
\text { Medical devices } \\
\text { Telecommunications terminal equipment } \\
\text { Low voltage equipment } \\
\text { Electromagnetic compatibility } \\
\text { Machinery (cranes etc.) } \\
\text { Pressure Equipment } \\
\text { Automotive products/vehicle components }\end{array}$ \\
\hline $\mathrm{EU}-\mathrm{CAN}$ & 1998 & $\begin{array}{l}\text { Telecommunications terminal equipment } \\
\text { Information technology equipment } \\
\text { Radio transmitters } \\
\text { Electromagnetic compatibility } \\
\text { Electrical safety } \\
\text { Recreational craft } \\
\text { Good manufacturing practices for medical products }\end{array}$ \\
\hline $\mathrm{EU}-\mathrm{CHE}$ & 2002 & $\begin{array}{l}\text { Machinery } \\
\text { Personal protective equipment } \\
\text { Toys } \\
\text { Medical devices } \\
\text { Gas appliances and boilers } \\
\text { Pressure vessels } \\
\text { Telecommunications terminal equipment } \\
\text { Equipment and protective systems intended for the use in } \\
\text { potential explosive atmospheres } \\
\text { Electrical equipment and electromagnetic compatibility } \\
\text { Construction plant and equipment } \\
\text { Measuring instruments and prepackages } \\
\text { Motor vehicles } \\
\text { Agricultural or forestry tractors } \\
\text { Good laboratory practice } \\
\text { Medicinal products GMP inspection and batch certification }\end{array}$ \\
\hline EU - ISR & 2000 & $\begin{array}{cl}\text { Chemicals good laboratory practice, applicable to } \\
- & \text { cosmetics } \\
- & \text { industrial chemicals } \\
- & \text { medicinal products/pharmaceuticals } \\
- & \text { food additives } \\
- & \text { animal feed additives } \\
- & \text { pesticides }\end{array}$ \\
\hline EU - JPN & 2001 & $\begin{array}{l}\text { Telecommunications terminal equipment and radio } \\
\text { equipment } \\
\text { Electrical products } \\
\text { Good laboratory practice for chemicals } \\
\text { Good manufacturing practice for medicinal products } \\
\end{array}$ \\
\hline EU - NZL & 1998 & $\begin{array}{l}\text { Medicinal products } \\
\text { Medical devices } \\
\text { Telecommunications terminal equipment } \\
\text { Low voltage equipment } \\
\text { Electromagnetic compatibility } \\
\text { Machinery (cranes etc.) } \\
\text { Pressure equipment }\end{array}$ \\
\hline EU - USA & 1999 & $\begin{array}{l}\text { Telecommunications equipment } \\
\text { Electromagnetic compatibility } \\
\text { Electrical safety } \\
\text { Recreational craft } \\
\text { Pharmaceutical good manufacturing practice } \\
\text { Medical devices }\end{array}$ \\
\hline EU-HUN ${ }^{23}$ & 2001 & $\begin{array}{l}\text { Machinery } \\
\text { Electrical Safety } \\
\text { Electromagnetic Compatibility } \\
\text { Gas Appliances } \\
\text { Hot Water Boilers } \\
\text { Medical Devices } \\
\text { Good Laboratory Practice } \\
\text { Good Manufacturing for Medicinal Products }\end{array}$ \\
\hline
\end{tabular}

${ }^{23}$ The EU-Hungary Agreement is technically not an MRA, but a PECA (Protocol to the Europe Agreement on Conformity Assessment and Acceptance of Industrial Products). PECAs are agreements 


\begin{tabular}{|c|c|c|}
\hline AUS - NZL & 1998 & All regulated products except those of national security concern \\
\hline AUS - SGP & 2002 & $\begin{array}{l}\text { Medicinal products GMP Inspection } \\
\text { Electrical and electronic equipment } \\
\text { Telecommunications equipment }\end{array}$ \\
\hline $\mathrm{CAN}-\mathrm{KOR}$ & 1997 & $\begin{array}{l}\text { Telecommunications equipment } \\
\text { Radio } \\
\text { Electromagnetic compatibility }\end{array}$ \\
\hline $\mathrm{CAN}-\mathrm{CHE}$ & 1998 & $\begin{array}{l}\text { Pharmaceuticals } \\
\text { Medical equipment } \\
\text { Telecommunications equipment }\end{array}$ \\
\hline EFTA - AUS & 1999 & $\begin{array}{l}\text { Medicinal products } \\
\text { Medical devices } \\
\text { Telecommunications terminal equipment } \\
\text { Low voltage equipment } \\
\text { Electromagnetic compatibility } \\
\text { Machinery (cranes etc.) } \\
\text { Pressure equipment } \\
\text { Automotive products/vehicle components }\end{array}$ \\
\hline EFTA - CAN & 2001 & Similar to EU - CAN MRA \\
\hline SGP - JPN & 2002 & $\begin{array}{lllll}\begin{array}{l}\text { Telecommunications } \\
\text { equipment }\end{array} & \text { terminal } & \text { equipment and radio } \\
\text { Electrical products } & & & \\
\end{array}$ \\
\hline SGP - NZL & 2001 & Electrical and electronic equipment \\
\hline SGP - USA & 2004 & Telecommunications equipment \\
\hline $\begin{array}{l}\text { Intra - EFTA } \\
\text { (CHE, ISL, LIE, NOR) }\end{array}$ & Approx. 1996 & $\begin{array}{l}\text { Machinery } \\
\text { Personal protective equipment } \\
\text { Toys } \\
\text { Medical devices } \\
\text { Gas appliances and boilers } \\
\text { Pressure vessels } \\
\text { Telecommunications terminal equipment } \\
\text { Equipment and protective systems intended for use in } \\
\text { potentially explosive atmospheres } \\
\text { Electrical equipment and electromagnetic compatibility } \\
\text { Construction plant and equipment } \\
\text { Measuring instruments and pre-packages } \\
\text { Motor vehicles } \\
\text { Agricultural and forestry tractors } \\
\text { Good laboratory practice } \\
\text { Medical products GMP inspection and batch certification }\end{array}$ \\
\hline $\begin{array}{l}\text { Intra - APEC } \\
\text { (AUS, BRN, CAN, CHL, CHN, } \\
\text { CHN Taipei, HKG, IDN, JPN, } \\
\text { KOR, MYS, MEX, NZL, PNG, } \\
\text { PER, PHL, RUS, SGP, THA, } \\
\text { USA, VNM) }\end{array}$ & 1999 & $\begin{array}{l}\text { Telecommunications } \\
\text { Electronic and electrical equipment (electrical safety) } \\
\text { Electromagnetic compatibility }\end{array}$ \\
\hline $\begin{array}{l}\text { CITEL (Inter-American } \\
\text { Telecomms Agreement) }\end{array}$ & 2000 & $\begin{array}{l}\text { Telecommunications equipment } \\
\text { Radio equipment } \\
\text { Electromagnetic compatibility } \\
\text { Electrical safety }\end{array}$ \\
\hline $\begin{array}{l}\text { Intra - ASEAN } \\
\text { (BRN, KHM, IDN, LAO, MYS, } \\
\text { MMR, PHL, SGP, THA, VNM) }\end{array}$ & 2000 & Electrical and electronic equipment \\
\hline
\end{tabular}

with candidate countries by which mutual recognition operates on the basis of the acquis communautaire (i.e., they differ from Mutual Recognition Agreements (MRAs) in that they make use of common technical rules and standards). 
APPENDIX V - Harmonization

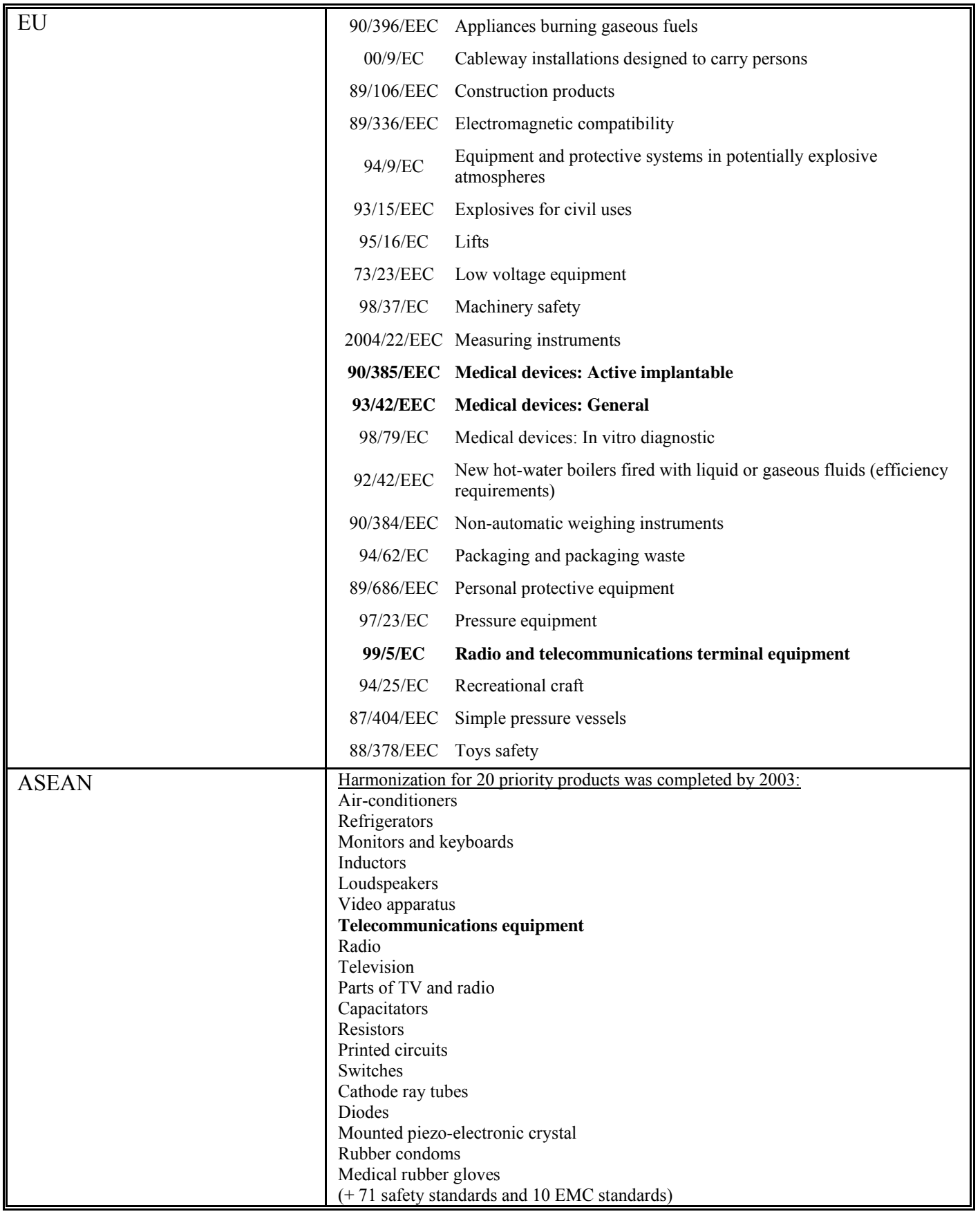




\section{APPENDIX VI - Regression Results}

VI.1 Stage 1 - Country-Pair Fixed Effects

(implies dropping all time-invariant country-pair characteristics)

\begin{tabular}{|c|c|c|c|}
\hline & $\begin{array}{l}\text { TELECOMMS } \\
\text { EQUIPMENT }\end{array}$ & $\begin{array}{l}\text { MEDICAL } \\
\text { DEVICES (HR } \\
\text { 1990) }\end{array}$ & $\begin{array}{l}\text { MEDICAL } \\
\text { DEVICES (HR } \\
\text { 1993) }\end{array}$ \\
\hline Dependent variable & prtelcoexp & prmedexp & prmedexp \\
\hline Ingdprep & $\begin{array}{l}0.21090 \\
(0.4173487)\end{array}$ & $\begin{array}{l}0.3942407 \\
(0.5618693)\end{array}$ & $\begin{array}{l}0.5083504 \\
(0.5634355)\end{array}$ \\
\hline lngdppcrep & $\begin{array}{l}-2.701938^{* * * *} \\
(0.8502425)\end{array}$ & $\begin{array}{l}0.684101 \\
(0.5857651)\end{array}$ & $\begin{array}{l}0.5994565 \\
(0.5887835)\end{array}$ \\
\hline lngdppar & $\begin{array}{l}0.0973794 \\
(0.33824599\end{array}$ & $\begin{array}{l}-3.488452 * * * \\
(0.539633)\end{array}$ & $\begin{array}{l}-3.626826^{* * *} \\
(0.5437054)\end{array}$ \\
\hline lngdppcpar & $\begin{array}{l}-1.076191 \\
(0.9102524)\end{array}$ & $\begin{array}{l}2.593148 * * * \\
(0.5397502)\end{array}$ & $\begin{array}{l}2.693682 * * * \\
(0.5352667)\end{array}$ \\
\hline Indistwces & $\mathrm{n} / \mathrm{a}$ & $\mathrm{n} / \mathrm{a}$ & $\mathrm{n} / \mathrm{a}$ \\
\hline comlang_off & $\mathrm{n} / \mathrm{a}$ & $\mathrm{n} / \mathrm{a}$ & $\mathrm{n} / \mathrm{a}$ \\
\hline contig & $\mathrm{n} / \mathrm{a}$ & $\mathrm{n} / \mathrm{a}$ & $\mathrm{n} / \mathrm{a}$ \\
\hline colony & $\mathrm{n} / \mathrm{a}$ & $\mathrm{n} / \mathrm{a}$ & $\mathrm{n} / \mathrm{a}$ \\
\hline lleither & $\mathrm{n} / \mathrm{a}$ & $\mathrm{n} / \mathrm{a}$ & $\mathrm{n} / \mathrm{a}$ \\
\hline isleither & $\mathrm{n} / \mathrm{a}$ & $\mathrm{n} / \mathrm{a}$ & $\mathrm{n} / \mathrm{a}$ \\
\hline WTO & $\begin{array}{l}0.7473382 * * * \\
(0.1429587)\end{array}$ & $\begin{array}{l}0.1681899 * \\
(0.0958562)\end{array}$ & $\begin{array}{l}0.1479443 \\
(0.0952302)\end{array}$ \\
\hline FTA & $\begin{array}{l}-0.6485442 \\
(0.3994121)\end{array}$ & $\begin{array}{l}-0.4973737^{* *} \\
(0.2020673)\end{array}$ & $\begin{array}{l}-0.6413389 * * * \\
(0.1901858)\end{array}$ \\
\hline MRA(sector) & $\begin{array}{l}-0.0571326 \\
(0.1990434)\end{array}$ & $\begin{array}{l}0.5530708 \\
(0.4278304)\end{array}$ & $\begin{array}{l}0.4329727 \\
(0.4099194)\end{array}$ \\
\hline HR(sector) & Dropped by Stata & $\begin{array}{l}-0.3705425 \\
(0.3933758)\end{array}$ & $\begin{array}{l}0.0646127 \\
(0.3581467)\end{array}$ \\
\hline HR(sector)oecd_sgp & $\begin{array}{l}0.5816262 * * \\
(0.2273636)\end{array}$ & $\begin{array}{l}0.3479144 * \\
(0.1923466)\end{array}$ & $\begin{array}{l}0.3922432 \\
(0.2399145)\end{array}$ \\
\hline HR(sector)_dev & $\begin{array}{l}-0.073575 \\
(0.0844198)\end{array}$ & $\begin{array}{l}-0.7103974 * * * \\
(0.1234612)\end{array}$ & $\begin{array}{l}-0.7088038 * * * \\
(0.1233057)\end{array}$ \\
\hline Pseudo-R ${ }^{2}$ & 0.4091 & 0.4641 & 0.4646 \\
\hline No. of observations & 10,347 & 19,188 & 19,188 \\
\hline
\end{tabular}

\footnotetext{
*** $\quad$ significant at the $1 \%$ level

** $\quad$ significant at the $5 \%$ level

* $\quad$ significant at the $10 \%$ level
} 
VI.2 Stage 1 - Exporter-, Importer- and Year-Fixed Effects

\begin{tabular}{|c|c|c|c|}
\hline & $\begin{array}{l}\text { TELECOMMS } \\
\text { EQUIPMENT }\end{array}$ & $\begin{array}{l}\text { MEDICAL } \\
\text { DEVICES (HR } \\
\text { 1990) } \\
\end{array}$ & $\begin{array}{l}\text { MEDICAL } \\
\text { DEVICES (HR } \\
\text { 1993) }\end{array}$ \\
\hline Dependent variable & prtelcoexp & prmedexp & prmedexp \\
\hline lngdprep & \begin{tabular}{|l|}
$0.9707997 * * *$ \\
$(0.0214004)$ \\
\end{tabular} & $\begin{array}{l}0.85233 * * * \\
(0.015611) \\
\end{array}$ & $\begin{array}{l}0.8510174 * * * \\
(0.0155708)\end{array}$ \\
\hline lngdppcrep & $\begin{array}{l}0.3637227 * * * \\
(0.0328771)\end{array}$ & $\begin{array}{l}0.4189913 * * * \\
(0.0201369)\end{array}$ & $\begin{array}{l}0.418886 * * * \\
(0.0200892)\end{array}$ \\
\hline lngdppar & \begin{tabular}{|l|}
$0.4336976^{* * * *}$ \\
$(0.0190137)$ \\
\end{tabular} & $\begin{array}{l}0.3779301 * * * \\
(0.0142132) \\
\end{array}$ & $\begin{array}{l}0.3759521 * * * \\
(0.0141995) \\
\end{array}$ \\
\hline lngdppcpar & \begin{tabular}{|l|}
$0.1673107 * * *$ \\
$(0.0195422)$ \\
\end{tabular} & $\begin{array}{l}0.003295 \\
(0.0153621) \\
\end{array}$ & $\begin{array}{l}0.0082063 \\
(0.015261)\end{array}$ \\
\hline Indistwces & $\begin{array}{l}-0.4456965 * * * \\
(0.0251412) \\
\end{array}$ & $\begin{array}{l}-0.4206721 * * * \\
(0.0174487)\end{array}$ & $\begin{array}{l}-0.4212635 * * * \\
(0.0174051)\end{array}$ \\
\hline comlang_off & \begin{tabular}{|l|}
$0.5900403 * * *$ \\
$(0.0479839)$ \\
\end{tabular} & $\begin{array}{l}0.4923552 * * * \\
(0.0364522)\end{array}$ & $\begin{array}{l}0.4892066^{* * *} \\
(0.0364333)\end{array}$ \\
\hline contig & $\begin{array}{l}-0.3267596 * * * \\
(0.1189587) \\
\end{array}$ & $\begin{array}{l}-0.6160077 * * * \\
(0.0801713)\end{array}$ & $\begin{array}{l}-0.6177519 * * * \\
(0.0802193)\end{array}$ \\
\hline colony & $\begin{array}{l}0.6496437 * * * \\
(0.1271608) \\
\end{array}$ & $\begin{array}{l}0.3966678 * * * \\
(0.0721545)\end{array}$ & $\begin{array}{l}0.3965382 * * * \\
(0.0720975)\end{array}$ \\
\hline lleither & \begin{tabular}{|l|}
0.0882706 \\
$(0.0666988)$ \\
\end{tabular} & $\begin{array}{l}0.080331 \\
(0.0505465) \\
\end{array}$ & $\begin{array}{l}0.0784831 \\
(0.0504791) \\
\end{array}$ \\
\hline isleither & $\begin{array}{l}-0.2863373 * * * \\
(0.0539094) \\
\end{array}$ & $\begin{array}{l}-0.41289611^{* * *} \\
(0.0410639) \\
\end{array}$ & $\begin{array}{l}-0.4158109 * * * \\
(0.0410465) \\
\end{array}$ \\
\hline WTO & \begin{tabular}{|l|}
$0.3293407 * * * *$ \\
$(0.0685001)$ \\
\end{tabular} & $\begin{array}{l}0.3066158^{* * *} \\
(0.0401811)\end{array}$ & $\begin{array}{l}0.3098297 * * * \\
(0.0401675)\end{array}$ \\
\hline FTA & \begin{tabular}{|l}
$0.2173083 * *$ \\
$(0.0938367)$ \\
\end{tabular} & $\begin{array}{l}0.4858283^{* * *} \\
(0.0740086) \\
\end{array}$ & $\begin{array}{l}0.4767499 * * * \\
(0.0737233) \\
\end{array}$ \\
\hline MRA(sector) & \begin{tabular}{|l|}
$0.5364777 * * *$ \\
$(0.102508)$ \\
\end{tabular} & $\begin{array}{l}0.5362539 * * * \\
(0.1408981) \\
\end{array}$ & $\begin{array}{l}0.4731507 * * * \\
(0.1301937) \\
\end{array}$ \\
\hline HR(sector) & $\begin{array}{l}-0.6853898^{*} \\
(0.3878362) \\
\end{array}$ & $\begin{array}{l}-0.1942201 \\
(0.1761689)\end{array}$ & $\begin{array}{l}-0.1373173 \\
(0.1936103)\end{array}$ \\
\hline HR(sector)oecd_sgp & \begin{tabular}{|l|}
$0.213935^{*}$ \\
$(0.1255157)$ \\
\end{tabular} & $\begin{array}{l}0.2862628 * * * \\
(0.0640037) \\
\end{array}$ & $\begin{array}{l}0.3588753 * * * \\
(0.0730391) \\
\end{array}$ \\
\hline HR(sector)_dev & \begin{tabular}{|l|}
-0.0360732 \\
$(0.0655061)$ \\
\end{tabular} & $\begin{array}{l}0.0069602 \\
(0.0447864) \\
\end{array}$ & $\begin{array}{l}-0.0478884 \\
(0.045776) \\
\end{array}$ \\
\hline No. of observations & 29,315 & 40,608 & 40,608 \\
\hline
\end{tabular}

Robust standard errors (clustering by country pair) are in brackets

*** $\quad$ significant at the $1 \%$ level

** $\quad$ significant at the $5 \%$ level

* $\quad$ significant at the $10 \%$ level 
VI.3 Stage 2 - Exporter-, Importer, and Year-Fixed Effects OLS Corrected for Heckman Selection Bias and Heterogeneity Bias via yhat

\begin{tabular}{|c|c|c|c|}
\hline & $\begin{array}{l}\text { TELECOMMS } \\
\text { EQUIPMENT }\end{array}$ & $\begin{array}{l}\text { MEDICAL } \\
\text { DEVICES (HR } \\
\text { 1990) } \\
\end{array}$ & $\begin{array}{l}\text { MEDICAL } \\
\text { DEVICES (HR } \\
\text { 1993) }\end{array}$ \\
\hline Dependent variable & Intelcoexp & Inmedexp & Inmedexp \\
\hline Ingdprep & $\begin{array}{l}0.1106261 \\
(0.6104795)\end{array}$ & $\begin{array}{l}1.75559 * * * \\
(0.225831)\end{array}$ & $\begin{array}{l}1.692831 * * * \\
(0.2294447)\end{array}$ \\
\hline lngdppcrep & $\begin{array}{l}1.746018 * * * \\
(0.6607502)\end{array}$ & $\begin{array}{l}0.2826898 \\
(0.2559243)\end{array}$ & $\begin{array}{l}0.3348802 \\
(0.2590798)\end{array}$ \\
\hline lngdppar & \begin{tabular}{|l|}
0.6503729 \\
$(0.6119718)$ \\
\end{tabular} & $\begin{array}{l}0.5847753 * * \\
(0.2310453)\end{array}$ & $\begin{array}{l}0.5174858 * * \\
(0.2391158)\end{array}$ \\
\hline lngdppcpar & $\begin{array}{l}1.844077 * * * \\
(0.6682847) \\
\end{array}$ & $\begin{array}{l}0.8184822^{* * *} \\
(0.2523145)\end{array}$ & $\begin{array}{l}0.8721921 \text { *** } \\
(0.2576831)\end{array}$ \\
\hline Indistwces & $\begin{array}{l}-1.01317 * * * \\
(0.0340775) \\
\end{array}$ & $\begin{array}{l}-0.9058929 * * * \\
(0.0193517)\end{array}$ & $\begin{array}{l}-0.9029701 * * * \\
(0.0193878)\end{array}$ \\
\hline comlang_off & $\begin{array}{l}0.508059 * * * \\
(0.0699714) \\
\end{array}$ & $\begin{array}{l}0.4443507 * * * \\
(0.0393899)\end{array}$ & $\begin{array}{l}0.4435004^{* * * *} \\
(0.0396502)\end{array}$ \\
\hline contig & $\begin{array}{l}-0.4813352 * * * \\
(0.1198314) \\
\end{array}$ & $\begin{array}{l}-0.3288868 * * * \\
(0.0661288)\end{array}$ & $\begin{array}{l}-0.3309807 * * * \\
(0.06659)\end{array}$ \\
\hline colony & $\begin{array}{l}0.6258515 \text { *** } \\
(0.1101568) \\
\end{array}$ & $\begin{array}{l}0.632416^{* * *} \\
(0.0621199)\end{array}$ & $\begin{array}{l}0.6396563 * * * \\
(0.0625021)\end{array}$ \\
\hline lleither & \begin{tabular}{|l}
$-0.7340733 * * *$ \\
$(0.2514461)$ \\
\end{tabular} & $\begin{array}{l}-0.62303 * * * \\
(0.1469085) \\
\end{array}$ & $\begin{array}{l}-0.6297676^{* * *} \\
(0.1480454) \\
\end{array}$ \\
\hline isleither & \begin{tabular}{|l|}
-0.0910346 \\
$(0.1117298)$ \\
\end{tabular} & $\begin{array}{l}-0.1391341^{* *} \\
(0.0655817)\end{array}$ & $\begin{array}{l}-0.1434634^{* *} \\
(0.066014)\end{array}$ \\
\hline WTO & $\begin{array}{l}\text { dropped to fulfill } \\
\text { exclusion restriction }\end{array}$ & $\begin{array}{l}\text { dropped to fulfill } \\
\text { exclusion restriction }\end{array}$ & $\begin{array}{l}\text { dropped to fulfill } \\
\text { exclusion restriction }\end{array}$ \\
\hline FTA & \begin{tabular}{|l|}
$0.3468349 * * *$ \\
$(0.0903682)$ \\
\end{tabular} & $\begin{array}{l}0.4192014 * * * \\
(0.0594404)\end{array}$ & $\begin{array}{l}0.4003746^{* * *} \\
(0.0589595)\end{array}$ \\
\hline MRA(sector) & \begin{tabular}{|l|}
-0.0865054 \\
$(0.0761364)$ \\
\end{tabular} & $\begin{array}{l}0.2213371 * * * \\
(0.0656481)\end{array}$ & $\begin{array}{l}0.1813529 * * * \\
(0.0637033)\end{array}$ \\
\hline HR(sector) & \begin{tabular}{|l}
$-0.2676397^{*}$ \\
$(0.1458103)$ \\
\end{tabular} & $\begin{array}{l}-0.4336519 * * * \\
(0.0819718)\end{array}$ & $\begin{array}{l}-0.4285944 * * * \\
(0.0796982) \\
\end{array}$ \\
\hline HR(sector)oecd_sgp & \begin{tabular}{|l|}
0.0682216 \\
$(0.1097871)$ \\
\end{tabular} & $\begin{array}{l}0.0734726 \\
(0.0631058) \\
\end{array}$ & $\begin{array}{l}0.09314 \\
(0.0624056) \\
\end{array}$ \\
\hline HR(sector)_dev & \begin{tabular}{|l|}
$0.2721036^{* *}$ \\
$(0.1072043)$ \\
\end{tabular} & $\begin{array}{l}0.0546173 \\
(0.0640355) \\
\end{array}$ & $\begin{array}{l}0.0250158 \\
(0.0631993) \\
\end{array}$ \\
\hline Yhat(sector) & \begin{tabular}{|l|}
$6.331152 * * *$ \\
$(0.4149608)$ \\
\end{tabular} & $\begin{array}{l}3.052422 * * * \\
(0.2058448) \\
\end{array}$ & $\begin{array}{l}3.064316^{* * *} \\
(0.2074153) \\
\end{array}$ \\
\hline No. of observations & 28,985 & 40,608 & 40,608 \\
\hline
\end{tabular}

*** $\quad$ significant at the $1 \%$ level

** $\quad$ significant at the $5 \%$ level

* $\quad$ significant at the $10 \%$ level 


\section{Bibliography}

Anderson, James E. (1979), “A Theoretical Foundation for the Gravity Equation”, American Economic Review, vol. 69

Anderson, James and E. van Wincoop (2003) "Gravity with Gravitas: A Solution to the Border Puzzle", American Economic Review, vol. 93

Anderson, James and E. van Wincoop (2004), “Trade Costs”, NBER Working Paper No.10480

ASEAN (1998) Report of the Taskforce on Developing a Roadmap to Mutual Recognition Agreements in ASEAN; report submitted to 11th meeting of the ACCSQ 11-12 March 1998

Baldwin, Richard E. (2000), "Regulatory Protectionism, Developing Nations and a Two-Tier World Trade System", Brookings Trade Forum, Washington D.C.; (reprinted in Maskus and Wilson (eds.), 2001, "Quantifying Trade Effects of Technical Barriers: Can it be done?" - University of Michigan Press, Ann Arbor)

Baldwin, Richard E. and F. Robert-Nicoud (2004), "Inter-industry and intra-industry trade with heterogeneous firms: Melitz made easy"

Baldwin, Robert E. (1970), "Non-tariff distortions of international trade”, Washington D.C.; Brookings Institution

Baier, Scott L. and J.H.Bergstrand (2005), "Do Free Trade Agreements Actually Increase Members' International Trade?” Federal Reserve Bank of Atlanta, Working Paper 2005-3

Bergstrand, Jeffrey H. (1989), “The Generalized Gravity Equation, Monopolistic Competition, and the Factor-Proportions Theory in International Trade", Review of Economics and Statistics, February $1989,71(1)$

Bernard, Andrew, J.Eaton, J.B.Jensen, and S.Kortum (2003), "Plants and Productivity in International Trade", American Economic Review, vol.93

Bergstrand, Jeffrey H. (1990), "The Heckscher-Ohlin-Samuelson Model, the Linder Hypothesis and the Determinants of Bilateral Intra-Industry Trade”, Economic Journal, December 1990, 100(403)

Blind, Knud and A.Jungmittag (2004), "The Impact of Standards on Macroeconomic Growth: A Panel Approach Covering Four Countries and Twelve Sectors" (forthcoming)

Brander, James and P.Krugman (1983), "A Reciprocal Dumping Model of International Trade", Journal of International Economics 15 (November):313-21

Casella A. (1996), "Free Trade and Evolving Standards", in Bhagwati J., Hudec R., edts., Fair Trade and Harmonization: Prerequisites for Free Trade?, vol.1, MIT Press, Cambridge, 119-156

Chaney, Thomas (2004) “Distorted Gravity”; MIT (job market paper)

Chen, Maggie X. and A. Mattoo (2004), “Regionalism in Standards: Good or Bad for Trade?”, World Bank (forthcoming)

Davis, Donald R. and D.E. Weinstein (2003), "Market Access, Economic Geography and Comparative Advantage: An Empirical Test", Journal of International Economics, vol. 59

David, P.A. and S.Greenstein (1990), "The Economics of compatibility standards: an introduction to recent research", Economics of Innovation and New Technology 1

Deardorff, Alan V. (1998), "Determinants of Bilateral Trade: Does Gravity Work in a Neo-Classical World?" in J.A. Frankel, ed. The Regionalization of the World Economy, Chicago: University of Chicago Press 1998 
DIN (Deutsches Institut für Normung) (2000), “Economic Benefits of Standardization“, Berlin: DIN

Dixit; Avinash and J. Stiglitz (1977), "Monopolistic Competition and Optimum Product Diversity", American Economic Review, 67, 297-308

Eaton, Jonathan and S.Kortum (2002), “Technology, Geography, and Trade”, Econometrica, vol. 70

Evans, Carolyn (2003), “The Economic Significance of National Border Effects”, America Economic Review, vol.93

Evenett, Simon J. and A.Venables (2002), "Export Growth in Developing Countries: Market Entry and Bilateral Trade Flows", mimeo

Farrell, J. and G.Saloner (1987), "Competition, Compatibility and Standards: The Economics of Horses, Penguins, and Lemmings", in Gabel, L. ed., Product Standardisation and Competitive Strategy, North Holland, Amsterdam

Feenstra, Robert C. (2002), "Border Effects and the Gravity Equation: Consistent Methods for Estimation", Scottish Journal of Political Economy, Vol.49

Feenstra, Robert C. (2003), “Advanced International Trade: Theory and Evidence”, Princeton University Press

Gandal, Neil and O. Shy (2001), "Standardization Policy and International Trade", Journal of International Economics 53

Ganslandt; Mattias and J.R.Markusen (2001), "Standards and Related Regulations in International Trade: A Modelling Approach", Chapter 4 in Maskus and Wilson (eds.), 2002, "Quantifying Trade Effects of Technical Barriers: Can it be done?" - University of Michigan Press, Ann Arbor

Haveman, Jon and D. Hummels (2004), "Alternative Hypotheses and the Volume of Trade: The Gravity Equation and the Extent of Specialisation", Canadian Journal of Economics, vol.37

Helpman, Elhanan (1987), "Imperfect Competition and International Trade: Evidence from Fourteen Industrial Countries", Journal of the Japanese and International Economics, vol.1

Helpman, Elhanan and P.Krugman (1985), "Market Structure and Foreign Trade”, Cambridge MA: The MIT Press

Helpman, Elhanan, M. Melitz and Y. Rubinstein (2004) "Trading Partners and Trading Volumes", forthcoming

Helpman, Elhanan, M. Melitz and Yeaple (2004), "Exports vs. FDI with Heterogeneous Firms", American Economic Review

Hoekman, Bernard, A. Mattoo and P. English (eds.) 2002, "Development, Trade and the WTO: A Handbook", WorldBank, Washington D.C.

ILAC Document: ILAC-I2:1994 "Testing, Quality Assurance, Certification, Accreditation" (www.ilac.org)

ILAC Document: ILAC-I3: 1996 “The Role of Testing and Laboratory Accreditation in International Trade" (www.ilac.org)

Jeanneret, M.-H. and T. Verdier (1996), "Standardization and Protection in a Vertical Differentiation Model, European Journal of Political Economy, vol.12 
Jungmittag, A./Blind, K./Grupp, H. (1999), Innovation, Standardisation and the Long-Term Production Function - A Cointegration Analysis for Germany, 1960 - 1996, in: Zeitschrift für Wirtschafts- und Sozialwissenschaften 119

Katz, M. and C. Shapiro (1994), "Systems Competition and Network Effects", Journal of Economic Perspectives, vol.8, no.2

Kende, M. (1992), "Strategic Standardization in Trade With Network Externalities”, mimeo (INSEAD, Fontainbleau)

Krugman, Paul R. (1980), "Scale Economies, Product Differentiation, and the Pattern of Trade", American Economic Review, 70, 950-959

Mantovani and M. Vancauteren (2003), "The Harmonization of Technical Barriers to Trade, Innovation and Export Behaviour: Theory with an Application to EU Environmental Data"

Maskus, Keith and J. Wilson (eds.), 2002, "Quantifying Trade Effects of Technical Barriers: Can it be done?" - University of Michigan Press, Ann Arbor

Mattoo, Aaditya and U. Subramanian (2003) "What would a Development-Friendly WTO Architecture really look like?", IMF Working Paper

Matutes, C. and P. Regibeau (1996), "A Selective Review of the Economics of Standardisation, Entry Deterrence, Technological Progress and International Competition”, European Journal of Political Economy, vol.12

McCallum, John (1995), "National Borders Matter: Canada-US Regional Trade Patterns", American Economic Review, vol. 85

Melitz, Marc (2003) "The impact of trade on intra-industry reallocations and aggregate industry productivity", Econometrica

Moenius (1999) “Three essays on Trade Barriers and Trade Volumes”, PhD dissertation; University of California, San Diego

OECD (2000), "An Assessment of the Costs for International Trade in Meeting Regulatory Requirements", Working Party of the Trade Committtee, TD/TC/WP(99)8/FINAL

OECD (2003), "Overview of Non-Tariff Barriers: Findings From Existing Business Surveys”, Working Party of the Trade Committee, TD/TC/WP(2002)38/FINAL

Pammolli, Fabio, M.Riccaboni, C.Oglialoro, L.Magazzini, G.Baio, N.Salerno (2005), "Medical Devices Competitiveness and Impact on Public Health Expenditure", CERM - Competitiveness, Markets and Regulation, Rome, Study prepared for the Directorate Enterprise of the European Commission

Pelkmans, Jacques (2003), "Mutual Recognition in Goods and Services: An Economic Perspective", European Network of Economic Policy Research Institutes, Working Paper No.16, March 2003

Rose, Andrew (2000), "One Money, One Market: Estimating the Effect of Common Currencies on Trade", Economic Policy, vol. 15

Rose, Andrew (2004), “Do We Really Know That the WTO Increases Trade?”, American Economic Review, vol. 94

Stata 7 Users' Guide and Reference Manuals, Stata Press (2001)

Subramanian, Arvind and S.-J. Wei (2003), "The WTO promotes Trade, Strongly But Unevenly", NBER Working Paper 10024 
Swann, Peter, P.Temple and M. Shurmer (1996) "Standards and Trade Performance: The UK Experience”, Economic Journal 106, September 1996

Tenreyo, Silvana and R. Barro (2003), “Economic Effects of Currency Unions”, NBER, Working Paper 9435

Tinbergen, Jan (1962), "Shaping the World Economy” (New York: The Twentieth Century Fund)

Thomas, R.Leighton, “Modern Econometrics”, Addison-Wesley (1997)

The Single Market Review; Subseries III: Dismantling of Barriers; Volume I: Technical Barriers to Trade, European Communities 1998

UNIDO (2004), Industrial Development Report, "Industrialisation, Environment and the Millenium Goals in Sub-Saharan Africa", Vienna

Vancauteren, Marc and Weiserbs (2003), "The impact of the Removal of Technical Barriers to Trade on Border Effects and Intra-Trade in the European Union”, Université Catholique de Louvain

Wallner, K. (1998) "Mutual Recognition and the Strategic Use of International Standards"; SITE, Stockholm School of Economics

Wei, Shang-Jin (1996), "Intra-national Versus Inter-national Trade: How Stubborn are Nations in Global Integration”, NBER Working Paper No. 5531

Wilson, John S. (2002) "Standards, regulation, and trade: WTO rules and developing country concerns" in Development, trade and the WTO: a handbook (ed. by Hoekman, Mattoo and English)

Wilson, John S. and T. Otsuki (2004), "Standards and Technical Regulations and Firms in Developing Countries: New Evidence from a World Bank Technical Barriers to Trade Survey", World Bank, Washington D.C.

Wooldridge, J., "Introductory Econometrics: A Modern Approach", 2000 South Western College Publishing (Thomson Learning)

World Trade Organization, World Trade Report 2005

\section{Websites}

\section{General:}

http://www.cia.gov/cia/publications/factbook/

http://www.cepii.fr/francgraph/bdd/bdd.htm

http://www.wto.org

http://www.unido.org/en/doc/26032

\section{MRAs and Harmonization:}

http://www.newapproach.org/Directives/DirectiveList.asp

http://www.aseansec.org/13820.htm

http://www.aseansec.org/4951.htm

http://www.dfait-maeci.gc.ca/canadaeuropa/country_swi_c-en.asp 
http://www.tga.gov.au/international/signmra.htm

http://www.tga.gov.au/international/eftamra.htm

http://www.coag.gov.au/meetings/140696/attachment_d.htm (re Trans-Tasman MRA)

http://www.raft-global.org/presentations/MRA_By-Industry-Canada_18May2000.ppt

http://europa.eu.int/comm/enterprise/international/indexb1.htm

http://www.apec.org

http://www.ts.nist.gov/ts/htdocs/210/gsig/mra.htm

http://europa.eu.int/scadplus/leg/en/s06011.htm 